\title{
كلمات مصرية قديمة في لغتنا العربية
}

\section{أ.د. سمير أديب.}

\section{Samir.adib@must.edu.eg}

ملخص:

بدراسة اللغة العربية واللغة المصرية القديمة تبين أنهما من أصل واحد

ثم افترقتا بمـا دخلههـا من القلب والإبدال كمـا حدث في كل اللغـات القديمـة.

فالألفاظ العربية لها مثيلها في اللغة المصرية القديمة، وقد بقيت اللغة القبطية وهي آخر مراحل تطور اللغة المصرية القديمة - متداولة في البلاد حتى القرن السابع الميلادي، ثم حلت محلها اللغة العربية، وأصبح استعمال اللغة القبطية مقصوراً على الطقوس في الكنائس.

واللغــة المصـرية القديمـة فيهـا الاســم الجامــ، والمشـقق، والفعـل بأزمانـه، والظرف (ظرف الزمان وظرف المكان)، وحروف العطف، والتذكير والتأنيث، ثم

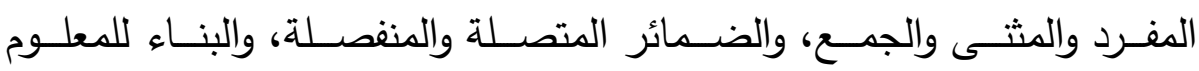
والمجهـول، والصـفة تتبع الموصـوف، والإضـافة المباشـرة ، والإضـافة بـاللام (كقولك كتاب محمد وكتاب لمحمد) ، ثم النسب بالياء ، وفيها الحال والتمييز ، والجملة الاسمية والجملة الفعلية...الخ.

* أستاذ الآثار والحضـارة المصرية القديمة، ورئيس قسم الآثار المصرية، جامعة مصر للعلوم والتكنولوجيا. 
ولعل الأكثر دلالة على صلة الرحم القديمة بين اللغة المصرية القديمة واللغـة العربية هو وجود صـلات جوهريـة بين قواعد النحو في كل منهما، على الرغم من اختلاف صور الكتابة بينهما، ومن ذلك:

وجـود حـروف الحساء والعـين والقـاف في اللغــة المصـرية القديمسة. شـيوع المصدر الثلاثي لأفعالها، غلبة الفعل المعتل الآخر فيها، سبق الفعل الفاعل، إلحاق الصفة بالموصوف، استخدام صيغة المثنى، إضـافة تاء التأنيث في نهاية بعض الأسماء والصفات المؤنثة، استخدام ياء النسبة، تمييز البعض عن الكل. الكلمات المفتاحية: لغة - قديمة - مصر - هيروغليفي - عربي.

تمنهـيـ

مصر اسم قدسته الأديان، وكرمته كتب السماء، إنه سجل مفاخر الإنسان، مرآه أمجاد البشر وصـرح الحضـارة بأسمى معانيها، إنـه التاريخ نفسـه بجميع حقائقه، ومن ثم فقد كان اسم مصر متلازماً مع المصريين منذ عصور التاريخ القديم، لـه أسـاس تاريخي، وجغرافي، وديني، ونفسي، وليس اسما نشـأ لمجرد ظروف سياسية يمكن تغييره في ظروف سياسية أخرى، فهو أقدم اسم يحمله أقدم بلد في الدنيا اسم حملته مصر الفرعونية ومصر القبطية ومصر الإسلامية ومصر الحديثة، على مدى آلاف السنين.

ولكل أمة تراث تحافظ عليه، وتتمسك به، يصعب عليها تغييره أو تبديله مهما أدخلت عليه المدنية من أثواب براقة، ومن المعروف أن المصري شديد 
الحرص على عاداته وتقاليده يتناقلها الخلف عن السلف، ذلك لأن اللغة حياة وتقاليد، وعقائد، بل ومقدسات أيضاً. وإذا كانت اللغة المصرية القديمة قد بدأت صوراً ورموزاً للأشياء، فهي قد أحسنت الرمز وساعدت العقل على العمل، ثم أصبحت بذلك كلاماً، ثم غدت وسيلة إلى غاية يريدها المتكلم.

ولمـا كانت ألفاظها مـن مـواطن لا تظهر فيها الحركات كمـا تظهر في الكـلام، فقد لجـأ المصـريون إلى إثبات مخصص لكل لفظ يثير إلى معنـاه، وحسناً فعلوا، فليس مجرد الصـوت الملفوظ، أو الكلمـة المكتوبـة بغير حركة، بكافٍ أو بكافية على أن يحمل في طياته الدلالة على المعنى. فاللغة المصرية إذن قديمة قدم الثعب الذي نشأ في هذا الوادي وتكلم بها.

والذي ينظر في اللغـة المصرية القديمـة وسيرتها، يرى أنها لغـة مطواعـة هيأت لها ظروف الحياة في الوادي ما لم يهيأ لكثير غيرها، ومن آيات قوتها وطواعيتها، أنها لم تقف جامدة، بل تطورت.

ومن الأمور الخارقة في تاريخ اللغات، أن تحيا وتزدهر اللغـة المصرية

القديمة لمدة تقرب من الخمسة آلاف عام. ومن المعروف أنه قلما تتعزل لغة عن بقية اللغات، وعادةً ما يكون لها شبه بلغات أخرى تكون معها مجموعة، وتتكون الأسرة اللغوية من هذه المجموعات.

هذا وتحتوي اللغة المصرية القديمة على ثلاثمائة أصل مشترك مـع اللغـة السامية وأكثر من مائة أصل مشترك مع اللغة الحامية، وعلى ذلك فإن الماضي 
اللغـوي يؤكـد الـليل الجغرافي. ولمـا كانـت مصـر تقـع في مفترق الطريـق

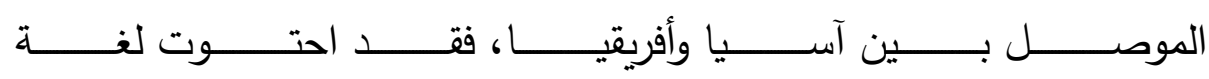
المصريين القدماء على ألفاظ يتجلى فيه الأثر الإفريقي والسامي، ومع ذلك فمن الضروري أن نقرر طرافة هذه اللغة وتفردها.

والطريف أن بعض الكلمات التي نستعملها الآن في أحاديثا اليومية أصلها مصري قديم، فلا نزال نعيش في الجو الذي كان يعيش فيه المصريون القدماء،

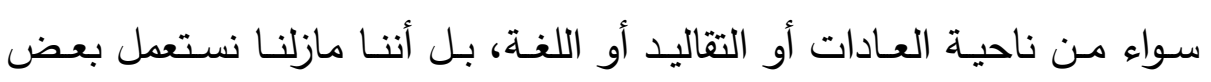
الكلمات نفسها، والعبارات التي كانوا يتكلمونها، دون أن نفطن إلى ذلك، رغم مضيّ أكثر من خمسة آلاف عام.

وبدراسة اللغة العربية واللغة المصرية القديمة تبين أنهما من أصل واحد

ثم افترقتا بمـا دخلهما مـن القلب والإبدال كمـا حدث في كل اللغـات القديمـة. فالألفاظ العربية لها مثيلها في اللغة المصرية القديمة، وقد بقيت اللغة القبطية وهي آخر مراحل تطور اللغة المصرية القديمة - متداولة في البلاد حتى القرن السابع الميلادي، ثم حلت محلها اللغة العربية، وأصبح استعمال اللغة القبطية مقصوراً على الطقوس في الكنائس.

وفى مصر الآن تختلف اللغة الدارجة في كل محافظة أو مركز ، عنها

في مكان آخر، فالتأثرات الجغرافية لها تأثير كبير على اللغة، فهي تكون اللغة كمـا تكون الأشـاص، واللغـة المصـرية القديمـة عامـل قوى في اللغـة العربيـة الدارجة، كالتقاليد المصرية القديمة في الأموات والأفراح. الخ. 


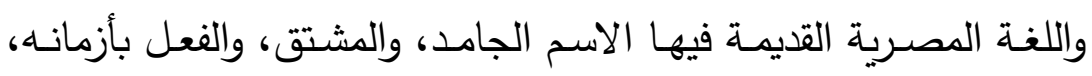
والظرف (ظرف الزمان وظرف المكان) ، وحروف العطف ، والتذكير والتأنيث ،

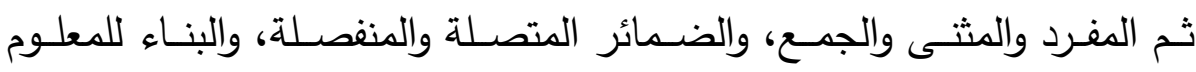
والمجهول ، والصـفة تتبع الموصـوف ، والإضـافة المباشـة ، والإضـافة باللام (كقولك كتاب محمد وكتاب لمحمد) ، ثم النسب بالياء ، وفيها الحال والتمييز ، والجملة الاسمية والجملة الفعلية. الخ.

ولعل الأكثر دلالة على صلة الرحم القديمة بين اللغة المصرية القديمة واللغة العربية هو وجود صـلات جوهريـة بين قواعد النحو في كل منهما، على الرغم من اختلاف صور الكتابة بينهما، ومن ذلك:

• وجود حروف الحاء والعين والقاف في اللغة المصرية القديمة.

• شيوع المصدر الثلاثي لأفعالها.

• غلبة الفعل المعتل الآخر فيها.

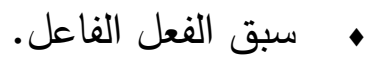
• إلحاق الصفة بالموصوف. • استخدام صيغة المثنى. • إضافة تاء التأنيث في نهاية بعض الأسماء والصفات المؤنثة.

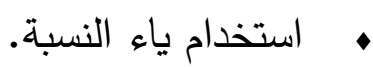
• مييز البعض عن الكل. 
• استخدام كاف المخاطب، وميم المكان، وميم الأداة ، ونون الجمع.. مثلها في ذلك مثل اللغة العربية. • وذلك فضـلاً عن كتابة الحروف السـاكنة وشبة اللينـة في كلماتها دون حروف الحركة أحياناً. • تشابه ضمير جمع المتكلم المطلق فيها مع مثله في اللغة العربية حين تأكيده بالأداة إن، فهو عند المصريين القدمان (إنن) وعند العرب (إننا). • تثابه كاف المخاطب المضاف إليه فيها مع العربية (ك). • اعتبار حرف النون حرفا أصـيلا في الضـير المتصـل بالنسبة للجمـع المتكلم فيها في حالتي الفاعل والمضـاف إليه، فكانوا يقولون (سجمن) كما نقول سمعنا ، ويقولون ( نبن ) كما نقول ربنا. • إلحاق واو الجماعة في بنهاية الفعل أحيانا، فيقولون (سجمو) كما نقول سمعوا. • استخدام ياء الإضافة للمتكلم. • استخدام ما تستخدمه أساليب اللغة العربية الحالية من الإضـافة المباشرة وغير المباشرة. • إلحاق الصفة بالموصوف • استخدام تمييز البعض من الكل. • استخدام الجملة الفعلية إلى جانب الجملة الإسمية. • إضـافة تاء المخاطب للمذكر والمؤنثة المفردين في إحدى صيغ الفعل الماضي، وكانت تقوم عندهم مقام الحال الحالي. 
• إضافة ميم المكان وميم الأداة إلى بعض أسمائها وأفعالها لتأليف أسماء

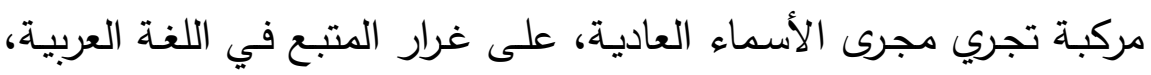

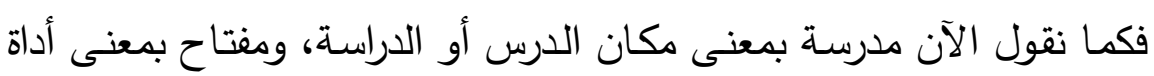

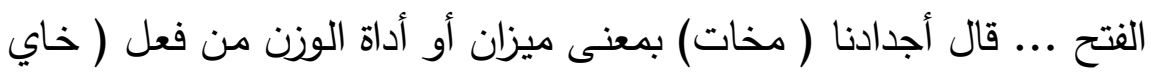
) بمعنى قاس ووازن ...الخ. • التوكيد المعنوي واللفظي. • التشـابه بين المصرية القديمـة والعربية في قضـايا الاسم، العدد، علامـة

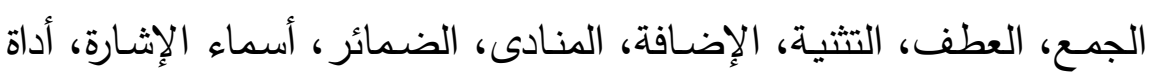

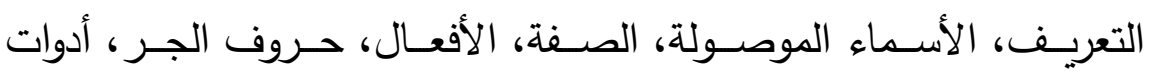

$$
\text { الاستفهام،...الخ. }
$$

• وأيضا بين تركيب الجملة، الاشتقاق، أدوات الاستثناء، إنّ "التوكيد"، نون

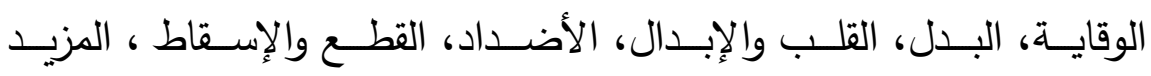

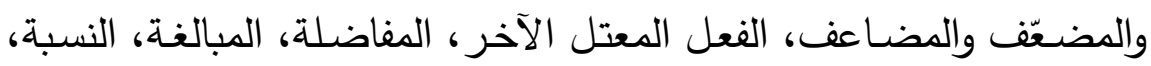

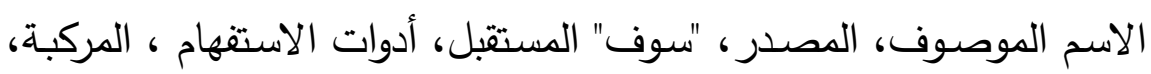
التعدية. وغير ذلك الكثير ...

ولاشك في أن التقارب في قواعد النحو بين اللغات لا يتأتى عادةً إلا عن طريق وحدة أصولها القديمة حتى وإن كانت أصولاً بعيدة. 
مقارنات بين قواعد اللغة المصرية القديمة واللغفة العببية

\begin{tabular}{|c|c|c|c|}
\hline \multicolumn{2}{|l|}{ اللغة العربية } & \multicolumn{2}{|l|}{ اللغة المصرية القديمة } \\
\hline 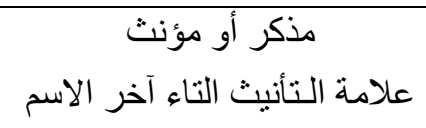 & الاسم & 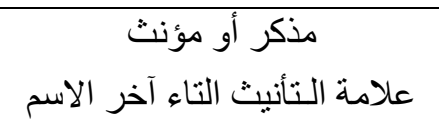 & الاسم \\
\hline 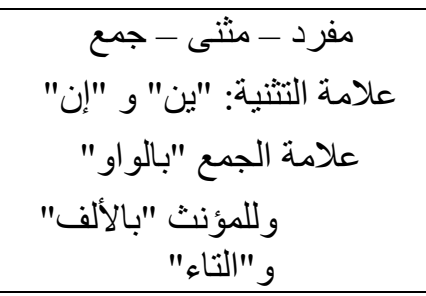 & العدد العد & 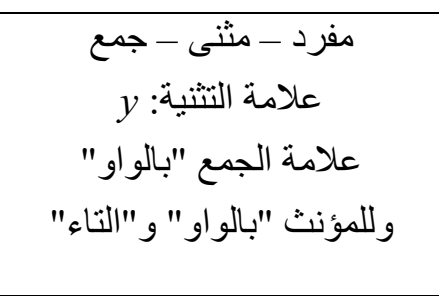 & العدد \\
\hline 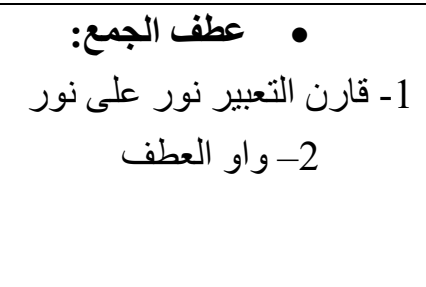 & & 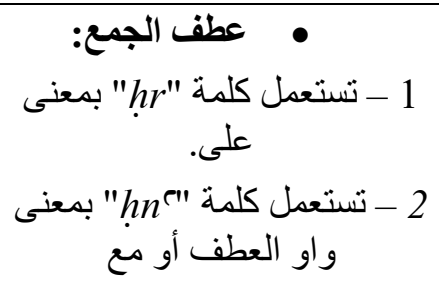 & العطف \\
\hline 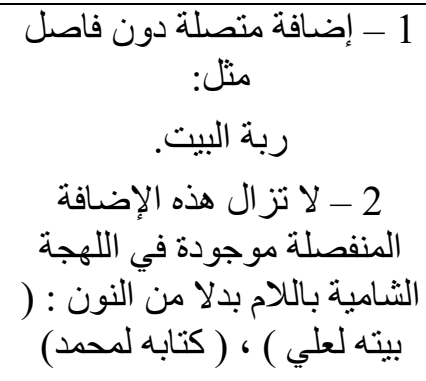 & الإضافة & 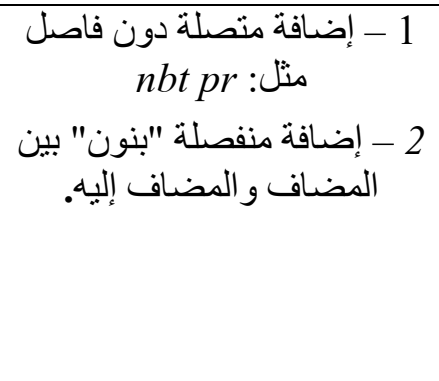 & الإضافة \\
\hline 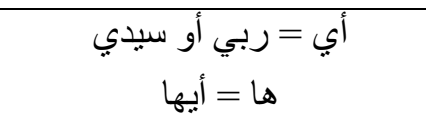 & المنادى & 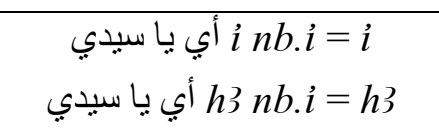 & المنادى \\
\hline 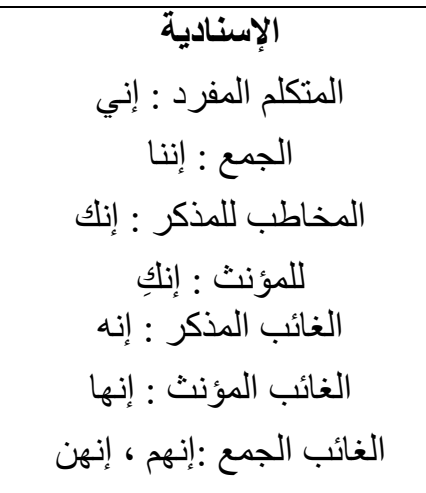 & الضمائر & 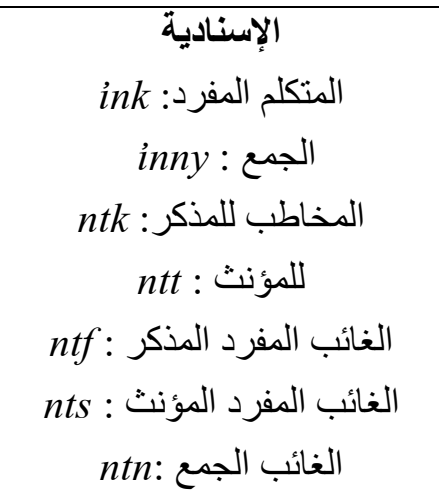 & الضمائر \\
\hline
\end{tabular}

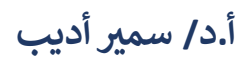

(كلمات مصرية قديمة في لغتنا العربية.) 
كما عرفت اللغة المصرية القيمة أبضا*

\begin{tabular}{|c|}
\hline العطف \\
\hline الإضافة \\
\hline أسماء الإشارة \\
\hline أداة التعريف \\
\hline الأسماء الموصولة \\
\hline الصفة \\
\hline حروف الجر \\
\hline أدوات الاستفهام \\
\hline النفي \\
\hline إن التوكيد \\
\hline القلب والإبدال \\
\hline الأضداد \\
\hline القطع والإسقاط \\
\hline الفعل المعتل الآخر \\
\hline المفاضلة والمبالغة والنسبة \\
\hline الاسم الموصوف والمصدر \\
\hline سوف المستقبل \\
\hline
\end{tabular}

* علي فهمي خثيم، آلهة مصر العربية، المجلد الثاني، القاهرة، 1998، ص 583.644

.. ولننظر الآن في طائفة من الكلمات التي تثير إلى قرابتها من اللغة العربية، وقد

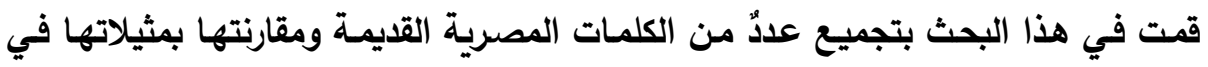

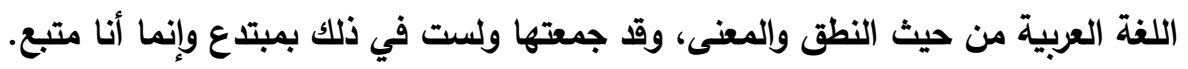




\begin{tabular}{|c|c|c|c|c|}
\hline المعى & النطق بالعربية & |الدلالة الصوتية & الكلمة الهيروغليفية & م \\
\hline رغب في ، أحبه. وفىى العربية آب أو أبا & آبى & $3 b j$ & & (i) \\
\hline 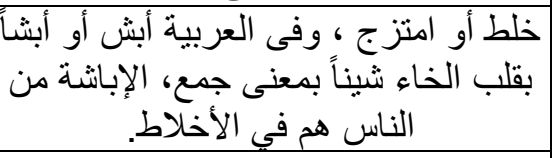 & إبخ & $3 b h$ & & (ii) \\
\hline رَفَّى & إياك & $\imath 3 k$ & & (iii) \\
\hline علا. & إعر | إ & $i e r$ & & (iv) \\
\hline لاب أب ظمأ، (و اللوب في العربية هو & إب & $i b$ & $m$ & (v) \\
\hline أسر أو أسبر. & إسر & iśr & مـد> & (vi) \\
\hline ق قوى ، أيّدَ & 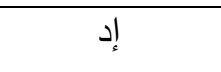 & id & & (vii) \\
\hline عظم أو كبر ، وفى العربية علا & عـا & 3 & & (viii) \\
\hline افتخر ، وهنى قريبة من العيَيَّة والعبية & عبىى & 'bj & & (ix) \\
\hline ابتلع ، التهم & عم & ${ }^{\top} m$ & & $(x)$ \\
\hline طاب ، عنّ له & عن - عنو & $e_{n w}-e_{n}$ & & (xi) \\
\hline عرك الثيء وتبحر فيه & عرق & 'rḲ & हैका & (xii) \\
\hline 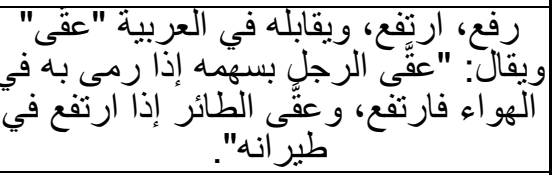 & عخى & Chj & 角育 & (xiii) \\
\hline عَطَسَ & عتش & etšs & $\square[60$ & $\left({ }^{\mathrm{xiv}}\right)$ \\
\hline وضح ولمع & وبخ & $w b h$ & 쇼옌 & $(x v)$ \\
\hline و هن ، تهدم ، انهار & وهن & $w h n$ & $\theta 0$ & (xvi) \\
\hline 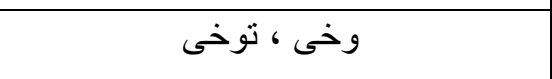 & 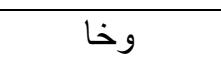 & wh3 & Sis & (xvii) \\
\hline سَوَّفَ (مع القلب و الإبدال) & وسف & $w s F$ & $8 x\}$ & (xviii) \\
\hline وسع & وسخ & wsh & 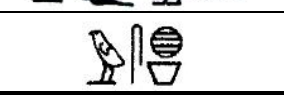 & (xix) \\
\hline
\end{tabular}


مجلة جامعة مصر للدراسات الإنسانية (العلوم الاجتماعية والإنسانية) مجلد 1 عدد 1 يناير (2021)

\begin{tabular}{|c|c|c|c|c|}
\hline 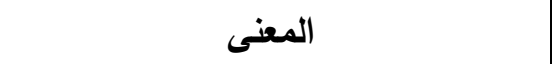 & النطق بالعربية & | الدلالة الصوتية & | الكلمة الهيروغليفية & م \\
\hline ونى ، أبطأ ، ويقابلها ففي العربية "دف" & ودف & $\overline{w d f}$ & Pi: & $(\mathrm{xx})$ \\
\hline وزن & ودن & $w d n$ & $\Rightarrow$ & $(x x i)$ \\
\hline وحى & وج & $w \underline{d}$ & 98: & (xxii) \\
\hline 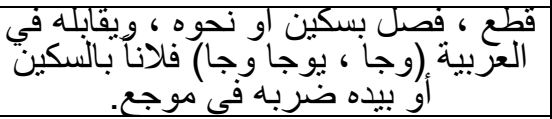 & 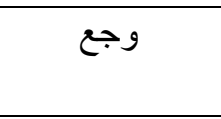 & $w \underline{d}^{e}$ & $\pi^{2}-8=0$ & (xxiii) \\
\hline بَرَقَ ، لمع & برق & $\begin{array}{l}b r \underset{K}{K} \\
b r g\end{array}$ & $\int_{0}^{\prime \prime} \Delta \infty$ & (xxiv) \\
\hline بَتَكَ ، ذبح & بتك & $b t k$ & $\iint_{0}^{0} \infty$ & $(x x v)$ \\
\hline 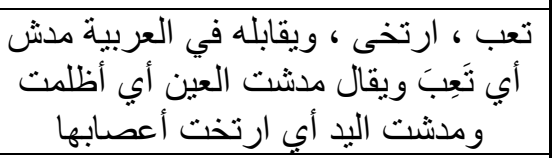 & 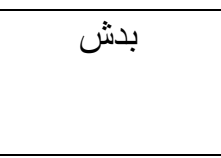 & $b d \check{s}$ & 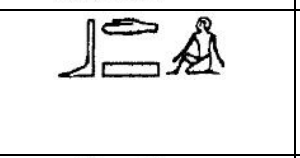 & (xxvi) \\
\hline حصل الرسوم ، جبى الضريية & بعبع & $p^{\top} p^{r}$ & S S & $\begin{array}{c}x x v i i) \\
(\end{array}$ \\
\hline تفل ، بصق & بعج & $p^{\top} g$ & $\stackrel{\square}{\Delta} \Delta$ & xxviii) \\
\hline بح أو انتهى & بح & $p h$ & ת תגים & (xxix) \\
\hline بصق & بسج & $p s g$ & 매, $\Delta, \infty$ & $(x x x)$ \\
\hline بطبط ، وطئ ، داس & بتبت & ptpt & תמת מם & $(x x x i)$ \\
\hline بصر & بتر & ptr & $\square_{0}^{0}\{0$ & $\begin{array}{c}x x x i i) \\
(\end{array}$ \\
\hline 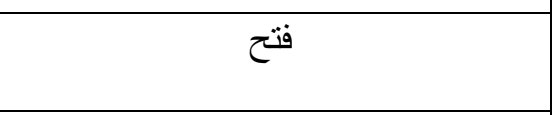 & بتح & pth & $\begin{array}{l}588 \\
\text { - }\end{array}$ & $\begin{array}{c}x x x i i i) \\
(\end{array}$ \\
\hline بطح & بتخ & pth & 囎 & $\underset{(}{\operatorname{xxxiv})}$ \\
\hline مد (مد الخطوة) & بد & $p d$ & $\Delta \Omega$ & $\begin{array}{c}x x y) \\
(\end{array}$ \\
\hline 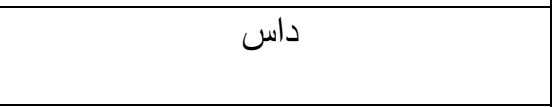 & 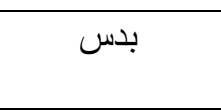 & $p d s$ & 口帧 & $\begin{array}{c}x \times x v i) \\
(\end{array}$ \\
\hline فلك & فخخ & $f h$ & 角公 & $\begin{array}{c}x_{x x \mathrm{xii}} \\
( \\
\end{array}$ \\
\hline
\end{tabular}

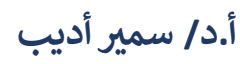

(كلمات مصرية قديمة في لغتنا العربية.)
} 
مجلة جامعة مصر للدراسات الإنسانية (العلوم الاجتماعية والإنسانية) مجلد 1 عدد 1 يناير (2021)

\begin{tabular}{|c|c|c|c|c|}
\hline 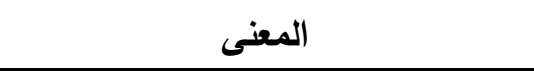 & النطق بالعربية & الدلالة الصوتية & الكلمة الهيروغليفية & م \\
\hline فط & فتقت & $f t f t$ & $\sum_{0}^{x} \Omega$ & $\begin{array}{c} \\
x \times x v i i i \\
(\end{array}$ \\
\hline فتق ، فدغ & فدق & $f d \underline{K}$ & $=\Delta$ & $\frac{1}{x x x i x)}$ \\
\hline مأأ عينه (أي قر أ ونظر بتمعن) & مأً & $m 33$ & & $(\mathrm{XI})$ \\
\hline اغتبط ، سعد & معر & $m^{\prime} r$ & & $(x \mid i)$ \\
\hline تحرك ، اهتز ، وقد يقابله في العربية & منمن & $m n m n$ & سبس & (xlii) \\
\hline 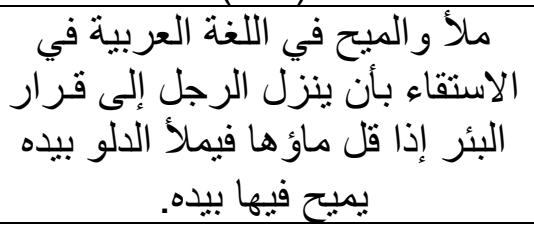 & مح & $m h$ & & (xliii) \\
\hline مشى مشى & مشتع & $m \check{s}^{r}$ & & (xliv) \\
\hline نعىى & نعىى & $n{ }^{r j}$ & & (xlv) \\
\hline 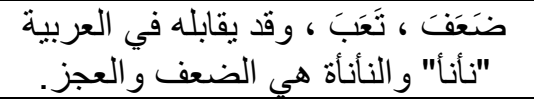 & ننى & $n n j$ & & $($ xlvi $)$ \\
\hline فط ، هرب ، نط & نقتقت & $n f t f t$ & $\operatorname{mm}_{0}^{\infty} \Omega$ & (xlvii) \\
\hline 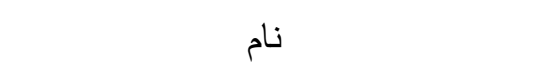 & 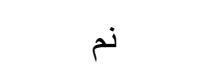 & $n m$ & & (xlviii $)$ \\
\hline نَهَهَ & نهم & $n h m$ & 问 & $(\mathrm{xlix})$ \\
\hline همهم & نهمهم & $n h m h m$ & 网四 & (I) \\
\hline ذاق ، استطعم ، لسب & نسب & $n s b$ & & (li) \\
\hline نش & 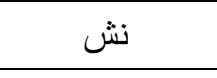 & $n \check{s}$ & ת & (lii) \\
\hline نكح ، جامع & نك & $n k$ & $\infty$ & (liii) \\
\hline نقنق & نججا & $\begin{array}{l}n g 3 g 3 \\
n g g\end{array}$ & 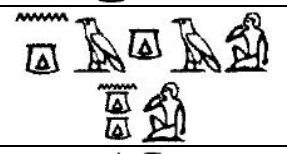 & (liv) \\
\hline نجا ، أنقذ & 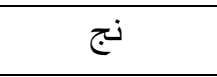 & $n \underline{d}$ & $\mathrm{~T}_{1}^{0}$ & (lv) \\
\hline نجر & نجر & $n \underline{d r}$ & $\stackrel{9}{9}$ & (Ivi) \\
\hline كَفَفْ & رفرف & $r f r f$ & $\begin{array}{l}\infty \\
x \text { ขn }\end{array}$ & (lvii) \\
\hline
\end{tabular}

$$
\text { أ.د/ سمير أديب }
$$

(كلمات مصرية قديمة في لغتنا العربية.) 
مجلة جامعة مصر للدراسات الإنسانية (العلوم الاجتماعية والإنسانية) مجلد 1 عدد 1 يناير (2021)

\begin{tabular}{|c|c|c|c|c|}
\hline المعى & النطق بالعربية & الدلالة الصوتية & الكلمة الهيروغليفية & م \\
\hline همهم ، زأر & همهم & hmhm & 口内回踢 & (Iviii) \\
\hline هلل ، فرح ، سُرَّ & هنو & $h n w$ & 同 & (lix) \\
\hline هنن ، ر اعى & هن & $h n n$ & & $(\mathrm{Ix})$ \\
\hline رد ، صـد & هد & $h d$ & & (lxi) \\
\hline ألبس & حبس & 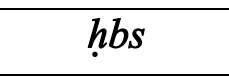 & & (Ixii) \\
\hline حَبَّسَ & حبس & $h \mathfrak{b s}$ & & (Ixiii) \\
\hline خضع ، أطاع ، عبد ، و هلى قريبة من & حنف & ḥnf & 810 & (Ixiv) \\
\hline حَسَبَ ، عد & حسب & ḥsb & & $(\mathrm{IxV})$ \\
\hline حطم & حتم & ḥtm & & (Ixvi) \\
\hline قدق ، جدع (فدع) ، (اسم) & حدق & $h d K$ & & (Ixvii) \\
\hline شع & خع & $h^{r}$ & & (Ixviii) \\
\hline خب & خبى & hpj & & (Ixix) \\
\hline خر ، سقط & خر & $h r$ & & $(I X X)$ \\
\hline خلخل ، هدم & خرخر & hrhhr & 官当 & (Ixxi) \\
\hline خسف ، طرد ، أبعد & خسف & hsf & ही। & (Ixxii) \\
\hline خَسِرَ ، جَنّبَ & خسر & hssr & 욯 & (Ixxiii) \\
\hline ختم & ختم & htm & & $\underset{(}{\text { Ixxiv })}$ \\
\hline خَسِيَُ & خسى & hsjj & $\rightarrow \infty$ & (IXXV) \\
\hline 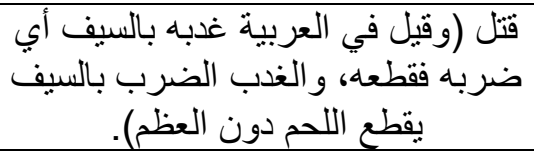 & غدب & $\underline{h} d b$ & $\Rightarrow \int$ 月 & $\left(\begin{array}{l}\text { Ixxvi }) \\
(\end{array}\right.$ \\
\hline انسـاب & ساب & $s 3 b$ & $-\infty$ & $\begin{array}{l}\text { Ixxvii }) \\
(\end{array}$ \\
\hline ذهب ، مضى ، زال & سبى & spj & $\Delta \Omega$ & $\begin{array}{c})_{(x \times v i i i} \\
(\end{array}$ \\
\hline صفا ، هدأ & سف & $s f$ & $\infty 6 \mathbb{Q}$ & Ixxix $)$ \\
\hline
\end{tabular}

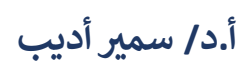

(كلمات مصرية قديمة في لغتنا العربية.) 
مجلة جامعة مصر للدراسات الإنسانية (العلوم الاجتماعية والإنسانية) مجلد 1 عدد 1 يناير (2021)

\begin{tabular}{|c|c|c|c|c|}
\hline المعنى & النطق بالعربية & الدلالة الصوتية & الكلمة الهيروغليفية & r \\
\hline سَوَّف & سودف & $s w d f$ & & $(\operatorname{lxxx})$ \\
\hline صبر ، بلغ & سبر & $s p r$ & $\infty$ & Ixxxi) \\
\hline ستلَّى & سرسر & $s r s r$ & $\infty$ & $\left({ }^{\text {Ixxxii }}\right)$ \\
\hline سحن ، سحق & سحم & sḥm & & $\underset{(x \times x i i i}{)}$ \\
\hline حرث (أي عمل سكة زراعية) & سكا & $s k 3$ & & $\begin{array}{c})_{(x x x i v} \\
(\end{array}$ \\
\hline شد ، حفر & شاد & $\check{s} 3 d$ & geres & Ixxxv) \\
\hline شَرَطَ (أو قطع إرباً) & 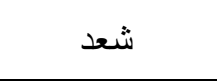 & $\bar{s}^{e} d$ & & $\left({ }^{\mid x x x v i}\right)$ \\
\hline سحق & شحق & šḥk & 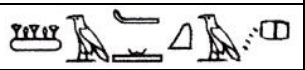 & (Ixxxvii) \\
\hline شتم ، سب & شتم & štm & एका & $\begin{array}{c})^{\prime} \\
x \times x \vee i i i \\
(\end{array}$ \\
\hline شُدا ، أنشد & 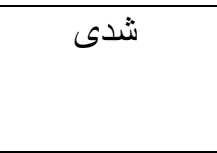 & $\check{s} d j$ & & $\begin{array}{c})_{\operatorname{lxxxix}}( \\
(\end{array}$ \\
\hline قاء & قاع & $k^{\circ}$ & $\triangle M=$ & $(\mathrm{xc})$ \\
\hline كمد ، اهتم & قمد & Kmd & $\Delta$ & (xci) \\
\hline قطف & قدف & $K d f$ & & (xcii) \\
\hline كَفَلَ & كفا & $K f 3$ & $x$ & (xciii) \\
\hline جَرَفت & 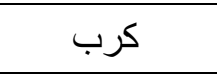 & $k r p$ & $\mathbb{R}^{2}$ & (xciv) \\
\hline كركر (من الضحك) & 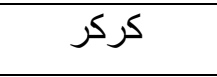 & $k r k r$ & $\begin{array}{l}\infty< \\
\infty<\end{array}$ & $(\mathrm{XCV})$ \\
\hline كبر ، شـاخ & كحكح & $k h k h$ & 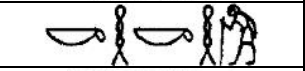 & (xcvi) \\
\hline رقص & كسكس & $k s k s$ & $\infty_{\rightarrow \infty} \rightarrow$ क्ष & $\begin{array}{c}\text { xcvii }) \\
(\end{array}$ \\
\hline قصقص & كتكت & $k t k t$ & مس山 & (xcviii) \\
\hline قوق أو كاكا & جاجا & $g 3 g 3$ & $\Delta \square \square$ \& & $(x \operatorname{cix})$ \\
\hline
\end{tabular}


مجلة جامعة مصر للدراسات الإنسانية (العلوم الاجتماعية والإنسانية) مجلد 1 عدد 1 يناير (2021)

\begin{tabular}{|c|c|c|c|c|}
\hline 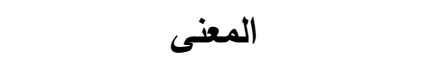 & النطق بالعربية & الالالة الصوتية & الكلمة الهيروغليفية & م \\
\hline كبب (أي طرح أرضاً) & جبجب & $g b g b$ & $\Delta \int \Delta \iint g$ & (c) \\
\hline لمح & جمح & gmh & $\Leftrightarrow$ & (ci) \\
\hline (جنب ، رفض) & جنف & gnf & 0 题 & (cii) \\
\hline تف & تف & $t f$ & & (ciii) \\
\hline 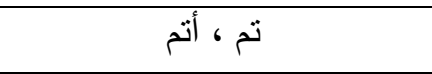 & تم & $t m$ & & (civ) \\
\hline طمس ، دفن & تمس & $t m s$ & $2 \infty-\pi$ & (cv) \\
\hline دشدش ، دش & تشتش & $t \grave{s} t \check{s}$ & & (cvi) \\
\hline أدى & دى & $d i$ & & (cvii) \\
\hline طبخ & دبخ & $d b h$ & $\infty \int \hat{\theta}$ & (cviii) \\
\hline نضب ، دهن (أى مسح بالزيت) & دهن & $d h n$ & & (cix) \\
\hline داس & دجس & $d g s$ & $\overrightarrow{\Delta \Delta} \| \Omega$ & (cx) \\
\hline ضرب (القلب) & دبدب & $d b d b$ & $\Rightarrow \int \Rightarrow \int \underline{D}$ & (cxi) \\
\hline ز & جعق & $\underline{d}^{\top} k$ & $\triangle \triangle \mathrm{D}$ & (cxii) \\
\hline
\end{tabular}

2- أسماء الصفات والمعنويات

\begin{tabular}{|c|c|c|c|c|}
\hline 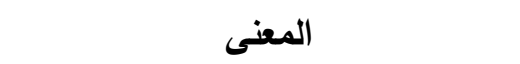 & النطق بالعربية & الدلالة الصوتية & الكلمة الهيروغليفية & م \\
\hline لون، بقلب الألف لاماً بالعربية & إيون & $i w n$ & $\Omega^{2}$ & (cxiii) \\
\hline توبيخ ، لوم & عاب & $3 p$ & $-n 80$ & (cxiv) \\
\hline 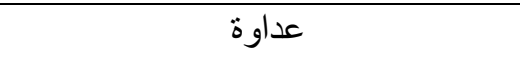 & عدت & ${ }^{e} d t$ & $\approx \vec{p} A P^{2}$ & $(\mathrm{cxv})$ \\
\hline الضوء ، الفجريص (أي ظهر بصيصال في العربية). & وبش وبش & wpš & & (cxvi) \\
\hline بركة ، هدية & برك & brk & $\frac{1}{d} \mathrm{SU}_{000}^{\infty}$ & (cxvii) \\
\hline بارع ، ماهر & برع & $p r^{e}$ & $\square \Lambda \Omega^{\square}$ & (cxviii) \\
\hline الموت ، الميت & موت & $m w t$ & 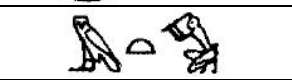 & (cxix) \\
\hline
\end{tabular}

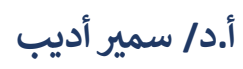

(كلمات مصرية قديمة في لغتنا العربية.)
} 
مجلة جامعة مصر للدراسات الإنسانية (العلوم الاجتماعية والإنسانية) مجلد 1 عدد 1 يناير (2021)

\begin{tabular}{|c|c|c|c|c|}
\hline المعنى & النظق بالعربية & الدلالة الصوتية & الكلمة الهيروغليفية & م \\
\hline منحة & منحت & $m n h j t$ & 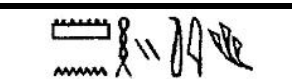 & $(\mathrm{cxx})$ \\
\hline المرض ، الثدة & مرت & $m r t$ & & (cxxi) \\
\hline ماهر & مهر & $m h r$ & 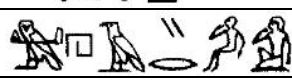 & (cxxii) \\
\hline ويقابلها في ، العربية رب & نب & $n b$ & & (cxxiii) \\
\hline ناكح & نكو & $n k w$ & $\sigma^{m m}$ & (cxxiv) \\
\hline نقمة ، مصيبة & نكمت & $n K m t$ & $\triangle \Delta$ & $(\mathrm{cxXv})$ \\
\hline لهب & رهب & $r h b$ & 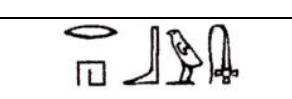 & (cxxvi) \\
\hline محاسيب & حسبو & hspw & 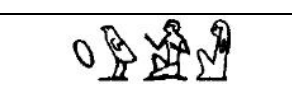 & (cxxvii) \\
\hline جاهل & خم & $h m$ & (1) & $\begin{array}{c}\text { cxxviii) } \\
(\end{array}$ \\
\hline صياح ، صراخ & سبح & $s b h$ & $1 \int R=5$ & (cxxix) \\
\hline سمير ، صديق & سمر & $s m r$ & 䧑 & (cxxx) \\
\hline قد ، هيئة ، صورة & قد & $K d$ & $\sqrt{0} \sqrt{2}$ & (cxxxi) \\
\hline نرف & ترف & $\underline{t} \operatorname{trf}$ & $\infty^{x}$ & (cxxxii) \\
\hline
\end{tabular}


3- وسائل النقل والآلات الزباعية وأدوات البناء وأسلحة الحرب

\begin{tabular}{|c|c|c|c|c|}
\hline المعنى & النطق بالعربية & الدلالة الصوتية & الكلمة الهيروغليفية & م \\
\hline ويبه (و هو مكيال قدره 18 لتراً) & إيبت & Ipt & ف뭄 & $\begin{array}{c}\operatorname{cxxxiii)} \\
(\end{array}$ \\
\hline عجلة & عجرت & 'grt & 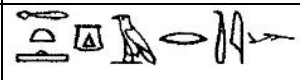 & $\begin{array}{c}\text { cxxxiv) } \\
(\end{array}$ \\
\hline منجل & ما & $m 3$ & & (cxxxv) \\
\hline رمح & مرح & $m r h$ & & cxxxvi) \\
\hline مركبة & مركبت & $m r k b t$ & $A=\infty \int \rho P_{2}-$ & $\underset{\text { cxxxvii }}{\text { ) }}$ \\
\hline حربة & حرب & hrp & ש & $\begin{array}{c} \\
\text { cxxxviii } \\
(\end{array}$ \\
\hline طين أو صلصـال & سين & $\sin$ & $10_{m}^{E}$ & $\begin{array}{c}\text { cxxix }) \\
(\end{array}$ \\
\hline سيف & سفت & $\begin{array}{l}s f \\
s f t\end{array}$ & & (cxl) \\
\hline سن سهم & سن & $s n$ & $\overline{\mathrm{mm}} \circlearrowright$ & (cxli) \\
\hline (أرض) شراقي & شرى-كا & $\check{s} r j-k 3$ & 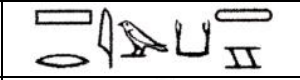 & (cxlii) \\
\hline حبل & شس & $\check{S} S$ & $=8$ & (cxliii) \\
\hline جص ، جبس & قج & $\underline{K d}$ & $\triangle \mathbb{N}_{0 \circ 0}^{\square}$ & (cxliv) \\
\hline
\end{tabular}

4- أسماء الأماكن والزمان

\begin{tabular}{|c|c|c|c|c|}
\hline المعنى & النطق بالعربية & الدلالة الصوتية & الكلمة الهيروغليفية & م \\
\hline الثهر (و"الأبد" في العربية من صفات & آبد & $3 b d$ & $\not{x}=$ & (cxlv) \\
\hline 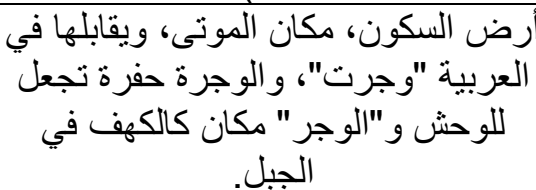 & إجرت & igrt & 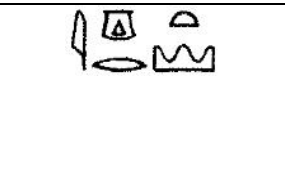 & $\begin{array}{c}\text { cxlvi) } \\
(\end{array}$ \\
\hline الو احة & واحت & w3ht & 0 & cxlvii) \\
\hline
\end{tabular}


مجلة جامعة مصر للدراسات الإنسانية (العلوم الاجتماعية والإنسانية) مجلد 1 عدد 1 يناير (2021)

\begin{tabular}{|c|c|c|c|c|}
\hline المعنى & النطق بالعربية & الدلالة الصوتية & الكلمة الهيروغليفية & r \\
\hline باب ، كهف & بابا & $b 3 b 3$ & & ) \\
\hline بئر & بار & $b 3 r$ & & cxlix) \\
\hline بكره ، الصبح & بكا & $b k 3$ & $\left.\int_{1}^{2}\right\}$ & (cl) \\
\hline متن ، طريق & مثن & $m \underline{t n}$ & & (cli) \\
\hline زمن & سمن & smn & & (clii) \\
\hline ساحة & سح & $s h$ & & (cliii) \\
\hline شونة & ش ش ت & $\check{s} n w t$ & $l_{m \mathrm{~m}} C$ & (cliv) \\
\hline قر ارة ، كهف & قررت & krrt & $\Delta_{0} \infty_{0}$ & (clv) \\
\hline جونه (زكيبة) & جون & $g w n$ & $\Delta \mathbb{P} \mathbb{R}_{0 \circ 0}^{0}$ & (clvi) \\
\hline ضبة & تا- باييت & $t 3-b 3 y t$ & 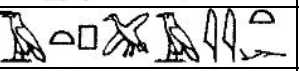 & (clvii) \\
\hline تلـ & تتر & $\operatorname{tnr}$ & $\operatorname{lnmm} 0 \frac{0}{\text { II }}$ & (clviii) \\
\hline
\end{tabular}

- 5 أسماء السوائل

\begin{tabular}{|c|c|c|c|c|}
\hline 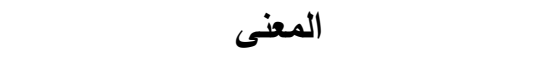 & النطق بالعزبية & اللالة الصوتية & الكلمة الهيروغليفية & م \\
\hline بركة & بركت & $\overline{b r k t}$ & 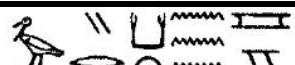 & (clix) \\
\hline اليم & يج & $y m$ & AA $\min _{\text {min }}$ & $(\mathrm{clx})$ \\
\hline 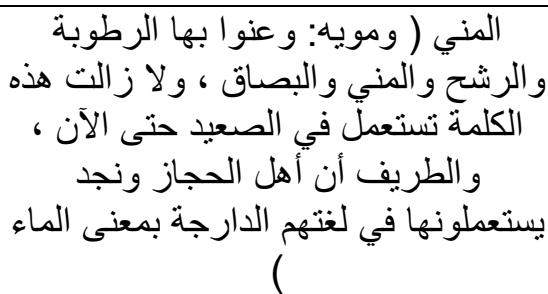 & مى & $m y$ & APf & (clxi) \\
\hline ماء ، بول & مو & $m w$ & $\min _{\text {min }}$ & (clxii) \\
\hline الزيت ، الدهن ، وهى ليست بعيدة عن & مرحت & $m r h t$ & 3800 & (clxiii) \\
\hline
\end{tabular}


مجلة جامعة مصر للدراسات الإنسانية (العلوم الاجتماعية والإنسانية) مجلد 1 عدد 1 يناير (2021)

\begin{tabular}{|c|c|c|c|c|}
\hline المعنى & النطق بالعربية & الدلالة الصوتية & الكلمة الهيروغليفية & م \\
\hline مخاضة & مشدت & $m \check{s} d t$ & $a_{0}^{\circ}$ & $\begin{array}{c}\text { clxiv) } \\
(\text { ) }\end{array}$ \\
\hline حمض & حمات & $h n 3 t$ & 8 & 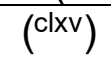 \\
\hline حمض ، خل & حمج & $h m \underline{d}$ & 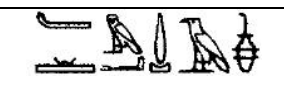 & clxvi) \\
\hline سمنة & سمى & $\check{s} m j$ & flf, & clxvii) \\
\hline زيت ،أو شجرة الزينون & جت & $\underline{d} t$ & Zृen & $\frac{1}{(c \mid x v i i i)}$ \\
\hline
\end{tabular}

\section{6 - أسماء الأدوات والملابسي}

\begin{tabular}{|c|c|c|c|c|}
\hline المعنى & النظق بالعربية & الدلالة الصوتية & الكلمة الهيروغليفية & م \\
\hline كأس & كاس & $k 3 s$ & $\bigcup_{-\infty} \theta$ & $($ (clxix) \\
\hline قلة & كرر & $k r r$ & บै०ठ & $\left(c^{c \mid x x}\right)$ \\
\hline قدر & قد & $k d$ & $\sqrt{0}$ & $\left({ }^{c l x x i}\right)$ \\
\hline مشط & مشدد & $m \check{m} d d$ & $\Delta\|\|_{11}$ & (clxxii) \\
\hline جلابية & جرب & $g r b$ & $\Delta \sim \int \mathbb{R}$ & (clxxiii) \\
\hline طبل & تبن & $t p n$ & & (clxxiv) \\
\hline
\end{tabular}

7- أجزاء الجســ

\begin{tabular}{|c|c|c|c|c|}
\hline 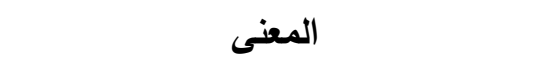 & النطق بالعربية & الدلالة الصوتية & الكلمة الهيروغليفية & م \\
\hline لَب ، قلب & إيب & $i b$ & 8 & $(\mathrm{clxxv})$ \\
\hline أذن ( ونطقها الآر اميون أودنا ) & 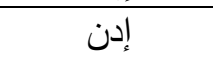 & $i d n$ & $\ell=0$ & (clxxvi) \\
\hline عين ، أعين & عين & $e^{\prime}$ & 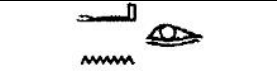 & $\begin{array}{c}\text { clxxvii) } \\
(\end{array}$ \\
\hline 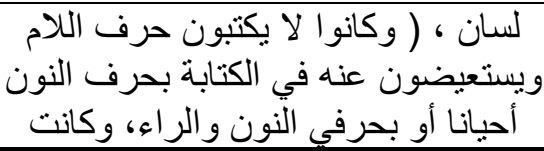 & 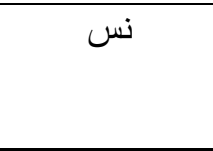 & $n s$ & p & $\underset{\substack{( \\
\operatorname{clxxviii}}}{(}$ \\
\hline
\end{tabular}


مجلة جامعة مصر للدراسات الإنسانية (العلوم الاجتماعية والإنسانية) مجلد 1 عدد 1 يناير (2021)

\begin{tabular}{|c|c|c|c|c|}
\hline المعنى & النطق بالعربية & الدلالة الصوتية & الكلمة الهيروغليفية & r \\
\hline تكتب في القبطية "لس"). & & & & \\
\hline 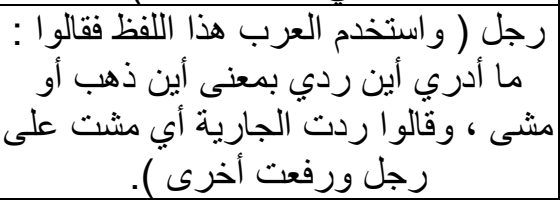 & رد & $r d$ & $\Leftrightarrow \int$ & (clxxix) \\
\hline ساق & سبق & spk & 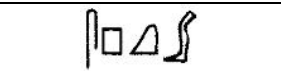 & (clxxx) \\
\hline 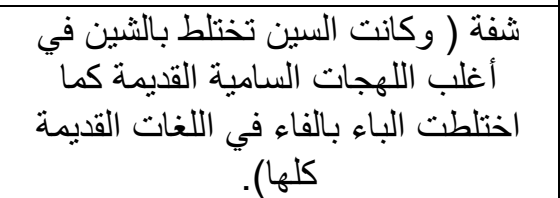 & سبت & spt & $\|_{0}^{\sigma_{0}}$ & $(\mathrm{cl} x \times x i)$ \\
\hline كف ، يد & كب & $k p$ & $\underset{\square}{\longrightarrow} \nrightarrow$ & $\begin{array}{c}\text { clxxxii) } \\
(\end{array}$ \\
\hline إلحركة ( حرفيا : صبع ، أغلب وكانت حروف اللغات السامية & جبع & $\underline{d} b^{c}$ & $\left.2 \int\right]-1$ & $\underset{(}{\operatorname{coxxiii}}$ \\
\hline
\end{tabular}

- 8

\begin{tabular}{|c|c|c|c|c|}
\hline المعنى & النطق بالعربية & الدلالة الصوتية & الكلمة الهيروغليفية & s \\
\hline طفل صغير & نني & $\overline{n n j}$ & & $\begin{array}{c}\text { clxxxiv }) \\
(\end{array}$ \\
\hline ست ، سيدة & ست & $s t$ & & $($ (clxxxv) \\
\hline عدو & سبى & $s b j$ & & $\begin{array}{c}\text { clxxxvi) } \\
(\end{array}$ \\
\hline صبى & سفى & $s f y$ & & $\underset{\substack{\text { clxxxvii } \\
(}}{2}$ \\
\hline صنو ، رفيق ، أخ & سنو & snw & & $\begin{array}{c}\text { ) } \\
\text { clxxxviii } \\
(\end{array}$ \\
\hline صغير ، طفل ، صبى & شيرى & $\check{s} r j$ & 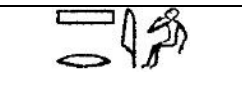 & $\begin{array}{c}\text { clxxxix }) \\
(\end{array}$ \\
\hline عذراء ، صبية & شيريت & $\check{s r j t}$ & 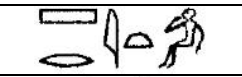 & (cxc) \\
\hline تاتا & تى تى ت & titi & $\Delta$ & (cxci) \\
\hline طفل (مع ملاحظة إبدال النون & تفن & $t f n$ & $x_{\min }^{0}$ & (cxcii) \\
\hline
\end{tabular}

أ.د/ سمير أديب

(كلمات مصرية قديمة في لغتنا العربية.) 
-9 أسماء الأعلام

\begin{tabular}{|c|c|c|}
\hline المعنى & النطق بالعربية & r \\
\hline 年 & 1. بيومي & $(\mathrm{cxciii})$ \\
\hline 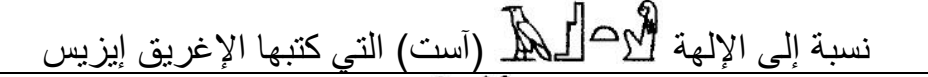 & 2. بيسه & \\
\hline 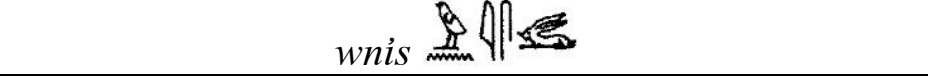 & 3. ونيس & \\
\hline بمعنى الصقر & 4. باخوم & \\
\hline بمعنى نور من كلمة (بسج) & 5 & \\
\hline 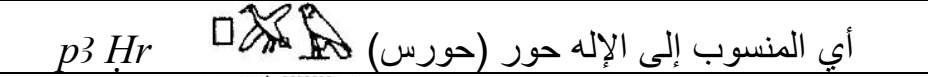 & 6. باهور & \\
\hline أي المنسوب إلى الإله إنبو (أنوبيس) & 7. & \\
\hline بمعنى عيد أو حظا & 8. & \\
\hline بمعنى حي هو الرب & 9 . شنودة & \\
\hline 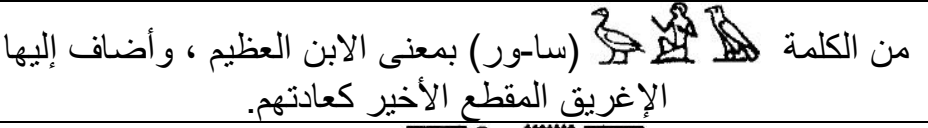 & 10. ساويرس & \\
\hline 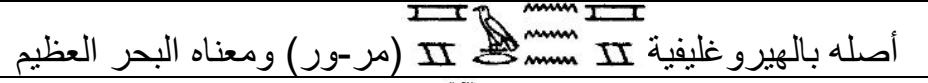 & 11. موريس & \\
\hline أصله الكلمة المصرية إل (سمر) بمعنى الصديق & 12. سمير & \\
\hline 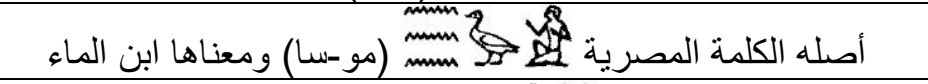 & 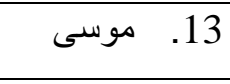 & \\
\hline أصلها \$ \$ \$ (مرى) بمعنى محبوبة & 14. مارى & \\
\hline
\end{tabular}

- وعبد الفتاح أصله عبد الإله " بتاح " ، وماري أصلها " ميري " أي محبوبـة

، وكذلك الأسماء: (إيبى ، بيبى ، توى ، تيتى ، ميمى ، فيفى ، خوى ، شرى ،

محب ، سوسو ، سيسى). 
10- أسماء الأثجار والنباتات والأعشاب والمحاصيل الزيرعية

\begin{tabular}{|c|c|c|c|c|}
\hline 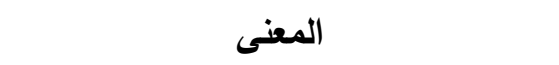 & النطق بالعربية & الالالة الصوتية & الكلمة الهيروغليفية & b \\
\hline الأمهات (للبلح) & أمهت & $3 m h t$ & & (cxciv) \\
\hline الكر ات (كما ذكر أيضاً باسم "كر هنا") & إياكت & $i 3 K t$ & & (cxcv) \\
\hline الينسون (كما ذكر أيضاً باسم "نيكون") & إينست & inst & & (cxcvi) \\
\hline 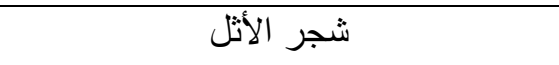 & إسر & $i s r$ & & (cxcvii) \\
\hline العدس & إدس & 'Ids & & $\begin{array}{c}\text { cxcviii) } \\
(\end{array}$ \\
\hline 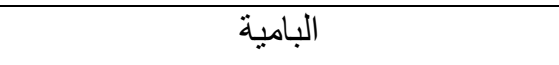 & بانو & b3nw & & (cxcix) \\
\hline البطيخ & بدوكا & $p d w k 3$ & & (cc) \\
\hline الفول & بور & $p w r$ & & (cci) \\
\hline 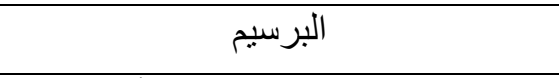 & برسم & prsm & & (ccii) \\
\hline ثمر ، بر ، وفى العربية "البر" أى الحنطة & برت & prt & & (cciii) \\
\hline البصل (كما ذكر أيضاً باسم "بدجر" & بسر & $p s r$ & & (cciv) \\
\hline البقول & بكن & $p k n$ & & $(\mathrm{ccv})$ \\
\hline الملوخية & منوح & $m n w h$ & & (ccvi) \\
\hline 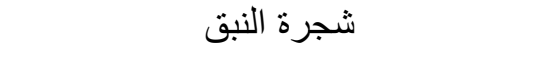 & 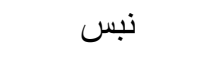 & $n b s$ & & (ccvii) \\
\hline الحب ، وفى العربية تطلق كلمة "النبارى" & 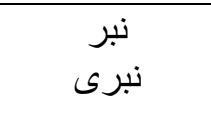 & $\begin{array}{c}n p r \\
n p r y\end{array}$ & & (ccviii) \\
\hline الرمان & 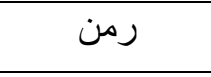 & $r m n$ & ש & (ccix) \\
\hline الحناء & حنو & $h n w$ & & $(\operatorname{ccx})$ \\
\hline زهرة (حريرة) & 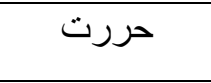 & hrrrt & $\sum_{0}^{8}$ & (ccxi) \\
\hline حزمة (شرش) & خرش & $h r \check{s}$ & $\sum^{\theta} \oiiint^{9}$ & (ccxii) \\
\hline شعير & سعر & $s^{e} r$ & {$\left[{ }^{\prime \prime m}\right]_{\infty}^{\infty}$} & (ccxiii) \\
\hline سوسن & سشن & $s \check{s} n$ & mme & (ccxiv) \\
\hline الشمر & شمر & $\check{s} m r$ & $\square \infty_{000}^{\infty}$ & $(\mathrm{ccXV})$ \\
\hline السمسم & شمشم & šmšm & $\square D_{000}$ & (ccxvi) \\
\hline
\end{tabular}


مجلة جامعة مصر للدراسات الإنسانية (العلوم الاجتماعية والإنسانية) مجلد 1 عدد 1 يناير (2021)

\begin{tabular}{|c|c|c|c|c|}
\hline 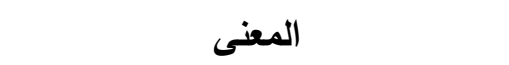 & النطق بالعربية & الالاية الصوتية & الكلمة الهيروغليفية & b \\
\hline الثيبية & شناب & $\check{s} n 3 b$ & & (ccxvii) \\
\hline شجر السنط & شنجت & $\check{s} n \underline{d} t$ & & $\begin{array}{c}\operatorname{ccxviii)} \\
(\end{array}$ \\
\hline القناء (كما ذكرت أيضاً باسم "قادث") & قادى & $k 3 d y$ & $\Delta M$ & \begin{tabular}{|l|} 
(ccxix) \\
\end{tabular} \\
\hline 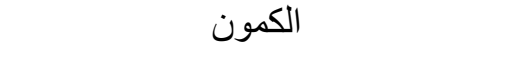 & 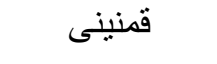 & Kmnyny & & $(\operatorname{ccx} x)$ \\
\hline القمح (كما ذكر أيضاً باسم "قمح") & قمحو & $K m h \underline{w}$ & & (ccxxi) \\
\hline 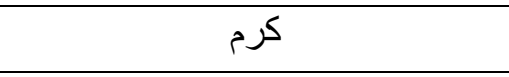 & كام & $\mathrm{k3m}$ & $U 1$ & (ccxxii) \\
\hline بوص & 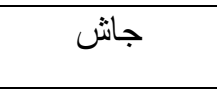 & $g 3 \check{S}$ & $\Delta \mathbb{1}$ & $\begin{array}{c}\text { ccxxiii }) \\
(\end{array}$ \\
\hline كمون & تبنو & tpnw & $\begin{array}{l}\square \operatorname{mim}_{\min } \\
\square \circ 00\end{array}$ & $\begin{array}{c}\text { coxxiv }) \\
(\end{array}$ \\
\hline 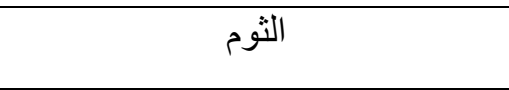 & 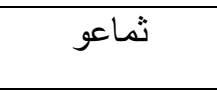 & $\operatorname{tg} 3^{\top} w$ & 1128 & $\begin{array}{c}\operatorname{ccxxv}) \\
(\end{array}$ \\
\hline دقيق & دقو & $d K w$ & $\Rightarrow B=\infty$ & $\begin{array}{c}\operatorname{ccx} x v i) \\
(\end{array}$ \\
\hline شجرة زيت & جت & $\underline{d} t$ & $\Rightarrow \mathrm{eq}$ & $\begin{array}{c})^{\prime} \\
\operatorname{ccxxvii} \\
(\end{array}$ \\
\hline 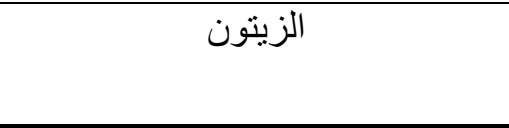 & جتنو & $\underline{d t n w}$ & केकी & $\begin{array}{c}\text { ) } \\
\text { ccxxviii } \\
(\end{array}$ \\
\hline
\end{tabular}

11

\begin{tabular}{|c|c|c|c|c|}
\hline المعنى & النطق بالعربية & الدلالة الصوتية & الكلمة الهيروغليفية & 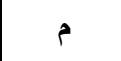 \\
\hline آيل (ذكر الغزال) & إير & iyr & 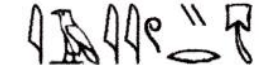 & $($ ccxxix) \\
\hline كلب & إو & $i w$ & वी & $\underset{(}{\operatorname{ccxxx})}$ \\
\hline حمار ، ويقابله في العربية "عير" & عا & 3 & $\infty$ & $\begin{array}{c}\operatorname{ccxxxi}) \\
(\end{array}$ \\
\hline 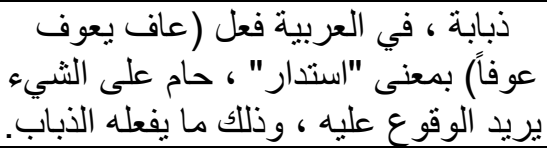 & عفف & eff & 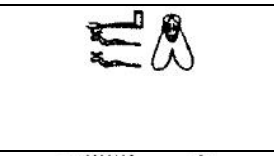 & $\underset{(}{\operatorname{ccxxxii}}$ \\
\hline عنزة & عنخت & enht & $f^{m}=0$ & (ccxxxiii) \\
\hline عظيم ، ويقابله في العربية طائر & ور & $w r$ & $\$$ & (ccxxxiv) \\
\hline
\end{tabular}

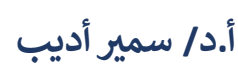

(كلمات مصرية قديمة في لغتنا العربية.) 
مجلة جامعة مصر للدراسات الإنسانية (العلوم الاجتماعية والإنسانية) مجلد 1 عدد 1 يناير (2021)

\begin{tabular}{|c|c|c|c|c|}
\hline المعنى & النطق بالعربية & الالالة الصوتية & الكلمة الهيروغليفية & b \\
\hline صوت القطة & ميو & miw & & \begin{tabular}{|l|}
$(\mathrm{ccxxxv})$ \\
\end{tabular} \\
\hline تمساح & مسح & $m s h$ & & \begin{tabular}{|l|} 
(ccxxxvi) \\
\end{tabular} \\
\hline جلد الحيوان & مسك & $m s k$ & & $\begin{array}{c}\text { ccxxxvii) } \\
(\end{array}$ \\
\hline نسر & نر & $n r$ & & \begin{tabular}{|c|}
) \\
$\operatorname{ccxxxviii}$ \\
(
\end{tabular} \\
\hline ذَنب & ساب & $s 3 b$ & & \begin{tabular}{|c|} 
(ccxxxix) \\
\end{tabular} \\
\hline سيسي & سسمت & ssmt & 000 & $(\mathrm{ccxl})$ \\
\hline قرد & قند & knd & 슬 $5 \pi$ & $($ ccxli) \\
\hline ضفذع & قرر & $k r r$ & $\Leftrightarrow 2$ & \begin{tabular}{|l|} 
(ccxlii) \\
\end{tabular} \\
\hline جحش ، غزال & جحس & $g h s$ & (4) ? & (ccxliii) \\
\hline جناح & جنح & $\underline{d n h}$ & $78=$ & (ccxliv) \\
\hline
\end{tabular}

\begin{tabular}{|c|c|c|c|c|}
\hline المعنى & النطق بالعربية & الدلالة الصوتية & الكلمة الهيروغليفية & م \\
\hline سمك البساريه & بسارى & bs $3 r y$ & $\int \mathbb{N}_{11}$ & (ccxlv) \\
\hline سمك البوري & برى & pry & 밍 & (ccxl \\
\hline
\end{tabular}

\section{3}

\begin{tabular}{|c|c|c|c|c|}
\hline المعنى & النطق بالعربية & الالالة الصوتية & الكلمة الهيروغليفية & 5 \\
\hline ألم & واوا & $w^{3} w^{3}$ & की 0 蝠 & ccxlvii) \\
\hline مرض ، أذى & مر & $m r$ & & ccxlviii) \\
\hline المرض ، الثدة & مرت & $m r t$ & & $\left(\frac{1}{(\operatorname{ccxlix})}\right.$ \\
\hline صداع ، ألم & ستع & $s t-c$ & 0 & (ccl) \\
\hline
\end{tabular}




\section{4}

\begin{tabular}{|c|c|c|c|c|}
\hline المعنى & النطق بالعربية & الدلالة الصوتية & الكلمة الهيروغليفية & م \\
\hline و احد & وع & $w^{r}$ & & (ccli) \\
\hline 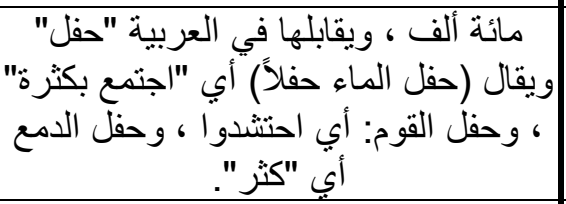 & حفن & $h f n$ & & (cclii) \\
\hline ثمانية & خمنو & hrmnw & שس山m & (ccliii) \\
\hline اثنان & سنو & snw & & (ccliv) \\
\hline
\end{tabular}

\section{5 - الضمائر}

ليس أدل على الصلة بين اللغة المصرية القديمة واللغة العربية من أن كثيراً من الألفاظ في اللغتين تكاد أن تكون واحدة في اشتقاقها ، فمثلاً:

\begin{tabular}{|c|c|c|}
\hline المعنى & النطق بالعربية & r \\
\hline باللغة العربية ، يقابلها في اللغة المصرية القديمة هِ فِ (إنك، إنوك) وهو & أنا & $\begin{array}{c}\text { (cclv) } \\
-1\end{array}$ \\
\hline 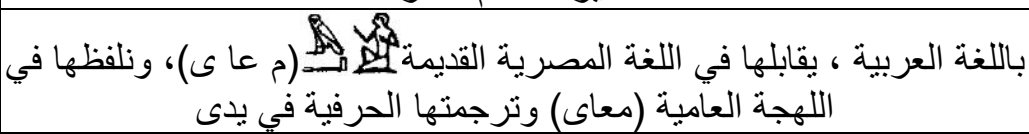 & معي & -2 \\
\hline 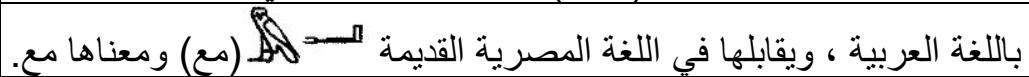 & 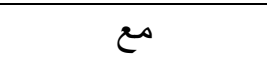 & -3 \\
\hline 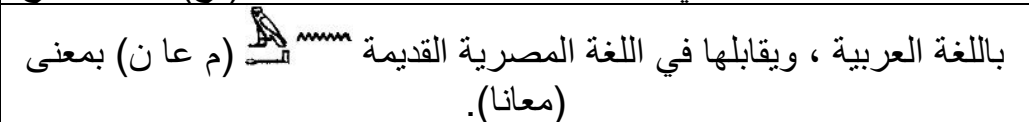 & معنا & -4 \\
\hline يقابلها نفس الحرف مل في اللغة المصرية القديمة. & كاف المخاطب في (معل) & -5 \\
\hline في اللغة العربية هي نفس التاء في اللغة المصرية القديمة ه & تاء التانيثث & -6 \\
\hline 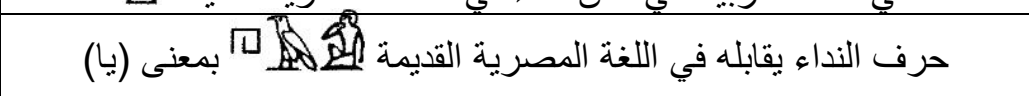 & يا & $\begin{array}{c}\left(\begin{array}{c}\text { (clvi } \\
-7\end{array}\right) \\
-7\end{array}$ \\
\hline
\end{tabular}

كذلك نلاحظ تشابه ضمير جمع المتكلم المطلق في اللغة المصرية القديمة مع مثيله في اللغة العربية من حيث

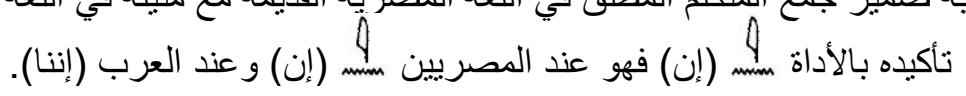


وقارن كورت زيتة بين الضميرين المصريين حم| |ج| ، الم (سو ، وسى) كما نقول هو وهى في لغتنا العربية.

\begin{tabular}{|c|c|c|}
\hline إن العربية التي تسبق المبتدأ & 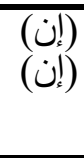 & $\left({ }^{\text {(cllvil }}\right)$ \\
\hline
\end{tabular}

\section{الشهور القبطية}

الثـهور القبطيـة هـي الثـهور المصـريـة القديمـة المرتبطــة بـالقدر والتـي

استخدمها المصـري القديم - ولا يزال كذلك المصـري المعاصـر - في كل مـا

يختص بالزراعـة والحصـاد. وتبـدأ السـنة الزراعيـة بشـهر (توت) ، وقد دعـا

المصـريون أول تـوت بـرأس السـنة أو إكليـل السـنة ، ولمـا جـاء الفـرس دعـوه

(نيروز) ومعناه باللغة الفارسية (يوم جديد). هذا وقد جعل الأقباط المسيحيون

بدء تاريخه أول توت عام 284م وأطلقوا عليه عصر الثهداء تذكاراً للذين نكل

بهم الإمبراطور الروماني "دقلديانوس".

وقد حملت هذه الثهور أسماء مصرية قديمة ، ثم قبطية ، ولا تزال اللغـة

العربية تحتفظ بمسميات هذه الثهور بنفس قيمتها الصوتية القديمة تقربياً.

\section{1. توت (11 سبتمبر - 10 أكتوبر):}

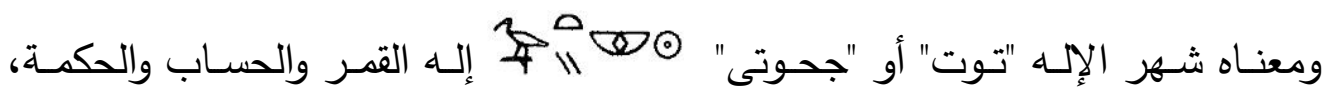
ويرمز له بالطائر المقد أبو منجل (إيبس). وشهر توت يأتي في أول السنة الزراعية مبشراً الفلاح ببدء الزراعة. ويقول العامة: - (توت ري ولا فوت) أي أن الزارع الذى لا يستطيع ري أرضه في هذا الثهر لا يستفيد بزراعتها. 
- و(توت يقول للحر موت) كناية عن بدء انخفاض درجة الحرارة واعتدال الجو.

- و(توت حاوى) أي أن الحاوي يتكلم عن علم ومعرفة بلسـان الإله (توت)

$$
\text { أو (جحوتى). }
$$

\section{2. بابه (11 أكتوبر - 9 نوفمبر):}

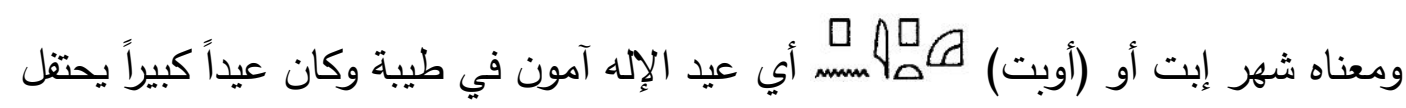
به الكهنة والحكام، في معبد الأقصر وفيما بينه وبين معبد الكرنك حيث ينتقل فيه آمون من شرق النيل إلى غربه لزيارة معابده الكائنة هناك(cclviii) ويقول العامة:

- - (بابه خُش واقفل الضرابة) إثارة إلى قفل "الضرابة"- أي الطاقة- اتقاء البرد.

\section{3. هاتور (10 نوفمبر - 9 ديسمبر)}

- أى شهر الآلهة حتحور لهـ إلهة الجمال والخصب، وفى هذا الثهر يبتسم وجه الأرض بجمال الزراعة.

- (هاتور أبو الدهب المنتور) كناية عن زراعة القهح الذي تشبه حبوبه الذهب.

$$
\text { 4. كيهك أو (كياك) (10 ديسمبر - } 8 \text { يناير) }
$$

- ومعناه شهر UEUU أي قرين مع قرين ، أو روح على روح ، أو اجتماع الروح مع الروح. ويقال:

- (كياك صباحك مساك قبل ما تفطر حضر عشاك) إثارة إلى قصر النهار في الشهر وطول ليله الذى تشتد فيه البرودة. 


\section{5. طوبة (9 يناير - 7 فيراير):}

- ربما مشتق من (شف بدت) ثم (شف بوتت) ، ثم تحور بعد ذلك إلى طوبـة(cclix) ، أو ربما

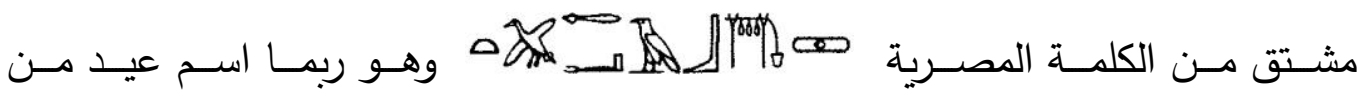
الأعياد(cclx) ، أو ربمـا أن كلمة (طوبـة) معناهـا الأعلى أو الأسمى وهو عيد القــح(cclxi). ويقال:

- (طوبـة تزيد فيه الثمس طوبـة) إثـارة إلى بدء طول النهار بمقدار قليل يعبر عنه بطوبة. - (طوبة يخلى الثابة كركوبة) إشارة إلى اشتداد البرودة. 6. أمشير (8 فبراير - 9 مارس):

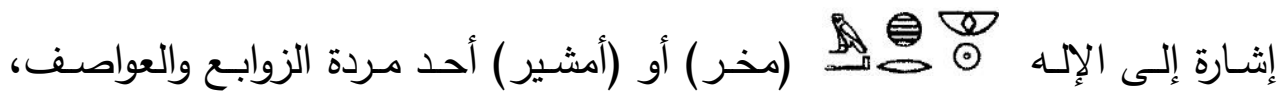
ويقال:

- أمشير أبو الزوابع الكتير ياخد العجوزة ويطير) إثارة إلى كثرة الزوابع. 7 . برمهات (10 مارس - 8 أبريل):

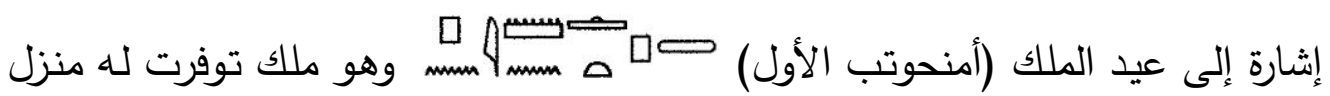
الأولياء عند خلفائه ونال قدسية كبيرة في مصر القديمة. ويقال: - - برمهـات روح الغـيط وهـات) كنايـة عمـا يحملـه الفـلاح مـن المحاصـيل الزراعية التي تتضـج في هذا الشهر . 


\section{8.}

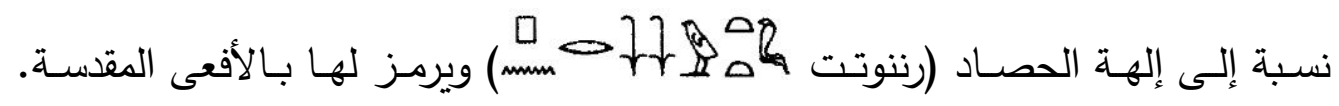
ويقال: - (برمودة دق بالعمودة) أي دق سنابل القهح بعد نضجه وفصل الحبوب من أغلفتها بالعصا الغليظة.

\section{9.}

- نسبة إلى الإله (خونسو) وكان يقام لله عيد في هذا الشهر • ويقال:

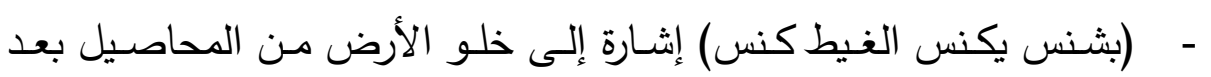
حصادها.

\section{0. يؤونة (8 يونيه- 7 يوليو):}

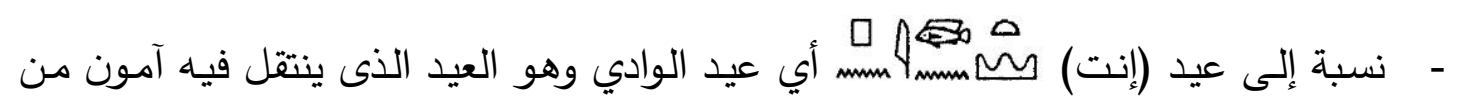

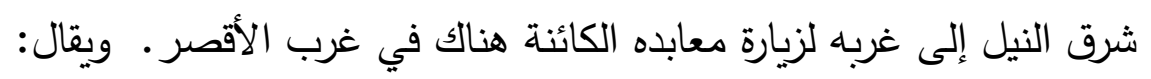
- (بؤونـة نقل القــح وتخزينـه للمؤونـة) إشـارة إلى درس القهـح في هذا الثـهر ونقله وتخزينه للمقدار المخصص للمؤونة. - (بؤونـة الحجر ينشف الميـه في الشجر) كنايـة عن شدة الحرارة في هذا

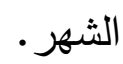




\section{1. أبيب (8 يوليو - 7 أغسطس):}

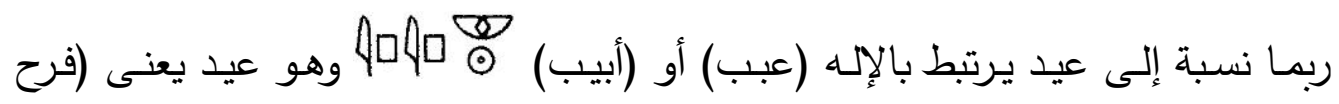

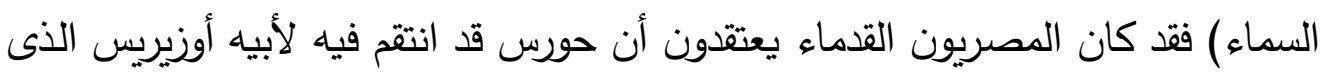

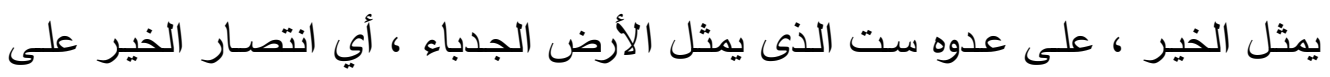

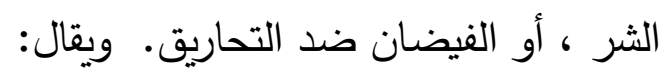

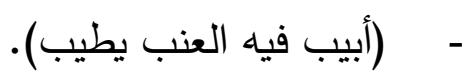

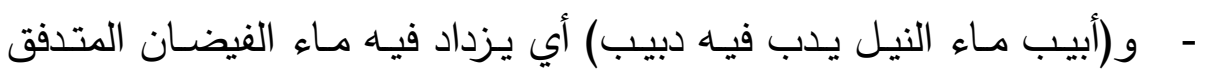
بصوته ورنينه. 12. مسرى (6 أغسطس - 5 سبتمبر):

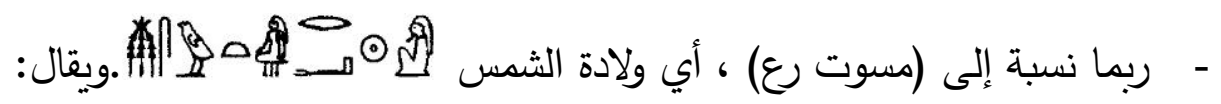
- - مسرى تجرى فيه كل ترعة عسرة). - (إن فاتلك مسرى ما تلقاش ولا كسرة) إثارة إلى اشتداد حرارة الثمس وزيادة مياه الفيضان الجارية في كل ترعة (cclxii). 


\section{متفرقات}

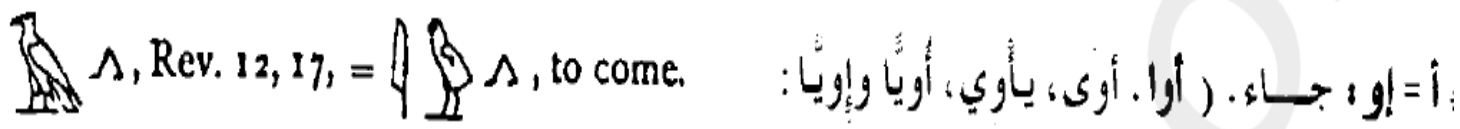

$$
\text { عاد ، وأوى : زهب) }
$$

علي فهمي خثيم ، البرهان على عروبة اللغة الدصرية القديمة ، القاهرة ،

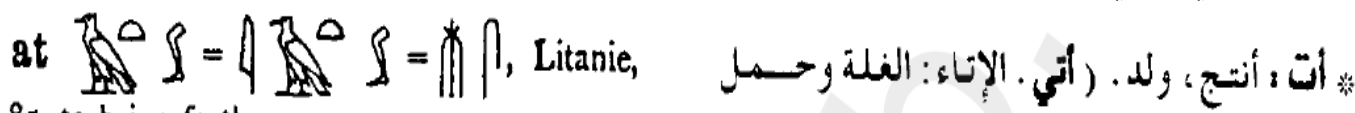

p. 85 , to bring forth.

$$
\text { النخل . أتت النخلة (وغيرها ) وآتت أثواً }
$$

$$
\text { وإتاء وإيثاء . أتت الماشية : منت ) }
$$

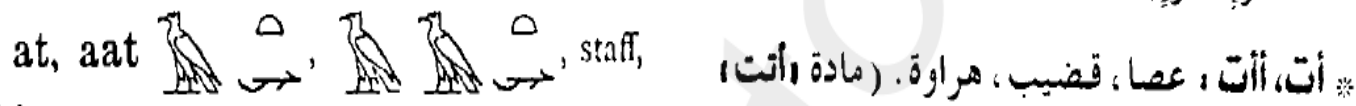
stick, stave.

تفيد الغلبة، والعصا أداة لها ) .

p.55

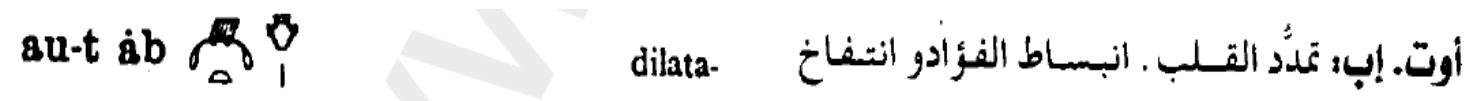
tion of heart, swelling of heart, pleasure, joy, gladness

القلب ، لذةة متعـة ، التعبسير الصسوفي:

$$
\begin{aligned}
& \text { البـسط والقبض (في القلب) = السعـادة } \\
& \text { والثقاء ، (توئيل اللب ) . } \\
& \text { p. } 57
\end{aligned}
$$

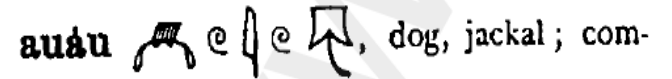

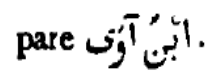

* أواو : كلب، ابن آوى. (ولوالَ. في مـادة (أَياًا ):

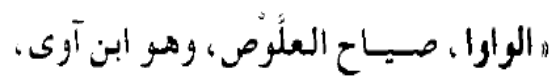
| إذاعاع) 
ah 8 管

evil, grief, disaster, prejudice; var.

ah-t 80 迎, entreaty, petition, prayer.

ah-ti 8011 , see 8011 .

- r on $n$ n

akhakh $\odot$ ness.

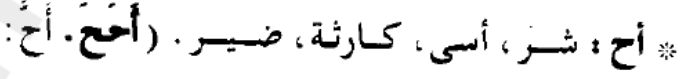

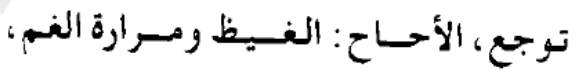
واشتداد الحزن) .

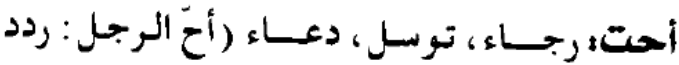

التنحنح في حلقه ، وسمعت له أحاحًا إذا لـا سمعته يتوجع . الأحيحة = الأحاح) . p.64

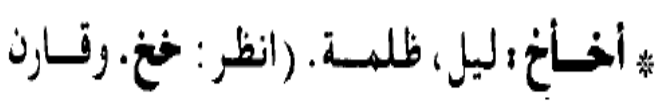
العربية: ليلة كاخُ، وظاخُ = مظلمة ) . p.65 ast $\int_{0}^{0}$ !, clay, earth, chalk (?); If $x$

$$
\text { 페 - }
$$

aqa $\triangle O$, filth, vomit $=\triangle$

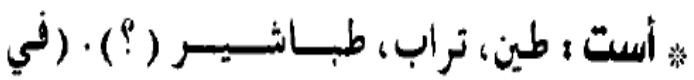

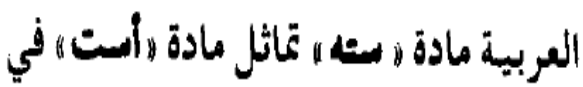
إفادة السفلية والقعرد = الأرضية) . p.67

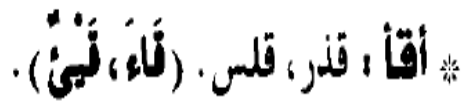


Aker an Earth. god, who had a lion's body with a head at each end of it ; Copt. \&kwps.
* أكر ، إله الأرض، الذي كان له جسمد أسد برأس على كل جـانب من جـانبيسه ـ ( في مادة "أكر " العـربيـة معسان متسعلة بالأرض:

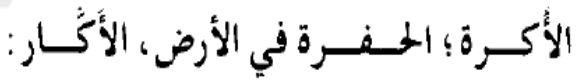

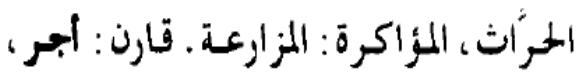
آجر"، وكذلك : حبر · و كذلك : عقر ) . p.69

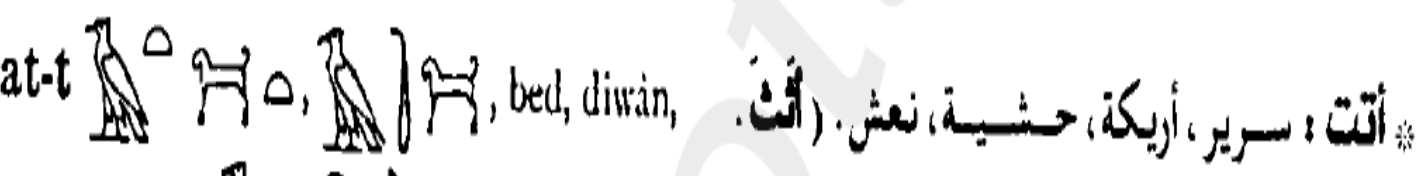
couch, bier; var. 0

الأثان: : أنواع الماع من ميأع البيت ونحوه).

$$
\text { p.71 }
$$

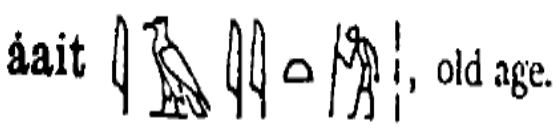

Aait 3 M०

the "old gods," gods of olden tine.

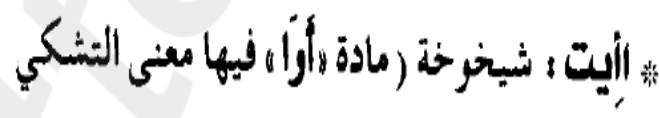
والتحـز والترجع، والداهية أو المصيبة، وهي علاعات الثيخوخة. تارل كذلك مادة

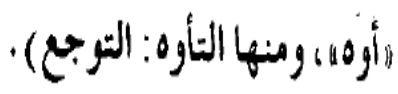
p.75 


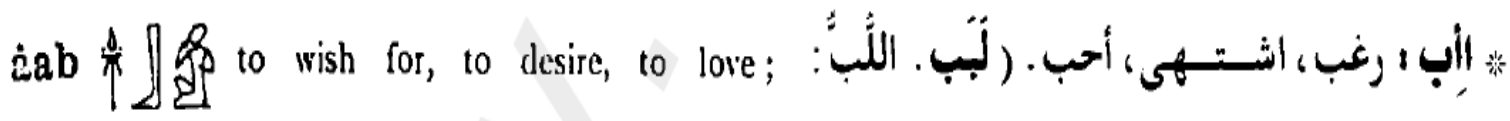

$$
\begin{aligned}
& \text { القلب ( مسيروضع العـر اطف في التـهسرر }
\end{aligned}
$$

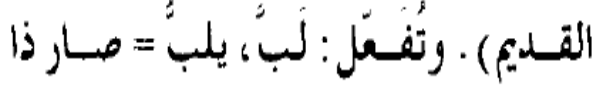

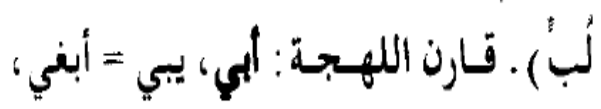

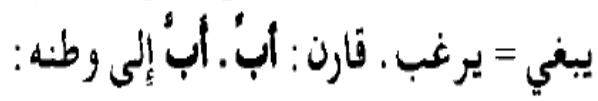

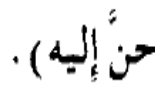

ảạ̣̄ $4-18-\infty$

the moon, Moon-god; Copt. 108,1008 , 1018 ; Heb. Iרי.

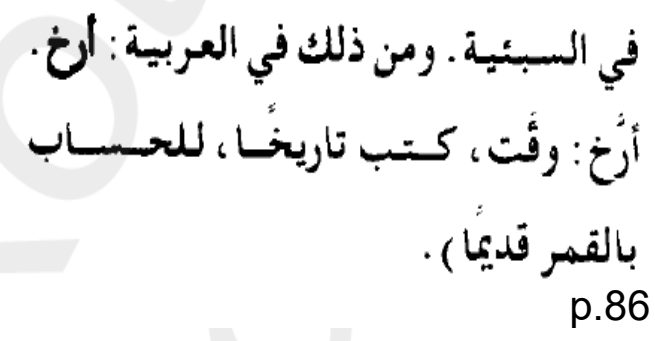

$$
\text { áu, áu-t }
$$

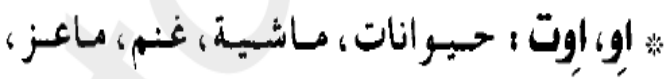
herds.

قطعان . (أرا . الأري: الطير المتجسمع في

$$
\begin{aligned}
& \text { مكان و احلد، سرب = قطيع ) . } \\
& \text { p.88 }
\end{aligned}
$$

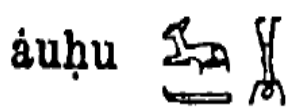

to lament
*اوحو ا انتحب. (وح). الرحوحة: مرت مع بحتح كالبكاء والنحـيب. فـارن : ورا .

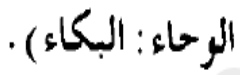

p.91 
aba 13 ,

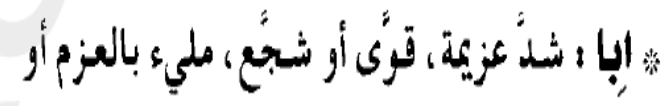
make strong or courageous, to be filled with soul or strength.

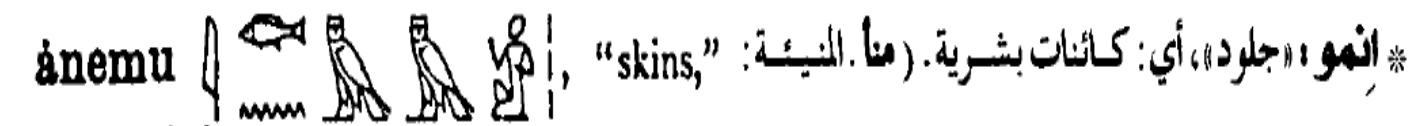
i.e, human beings.

المجلد، وخص الجلمل الملبوغ، لاحظ صلة (البشر)

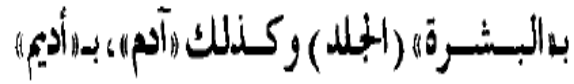

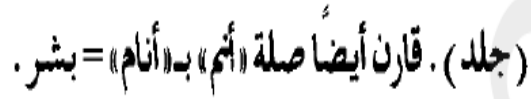

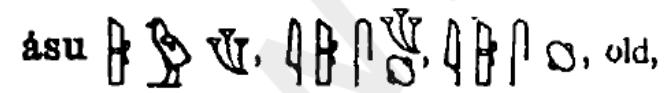

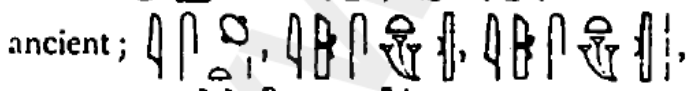
old, ruined: $\triangle A F$ P

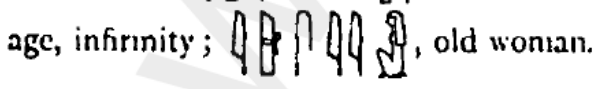

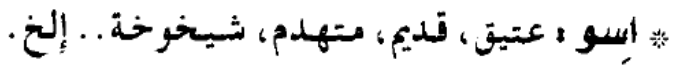

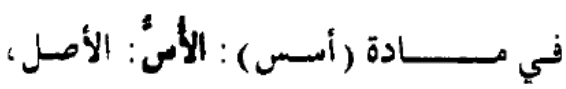
المبتدى، وأس" الدهر : أوله = قديم.

p.119 


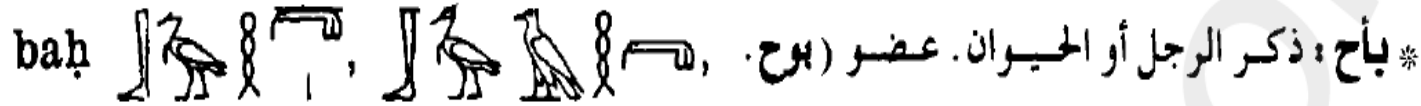

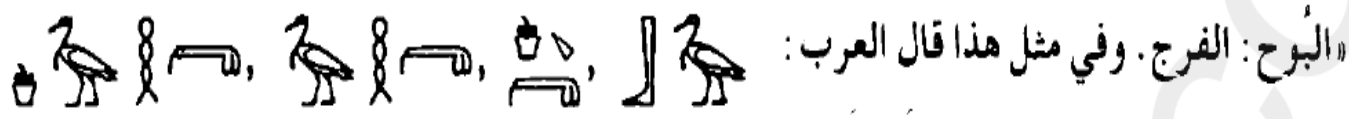
ا 1908, 311 (var. $\left.\int \& \neg 0\right)$, the phallus of man

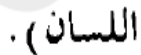
or animal, member; Copt. g\&\&.

bák $\int \mathcal{A} \Rightarrow$ \& Rec. 2?, 59, to twitter,

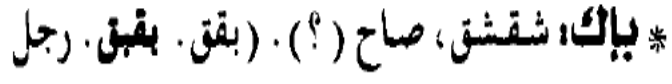
بقباق: كير الككلام، ميًاح) .

p.162

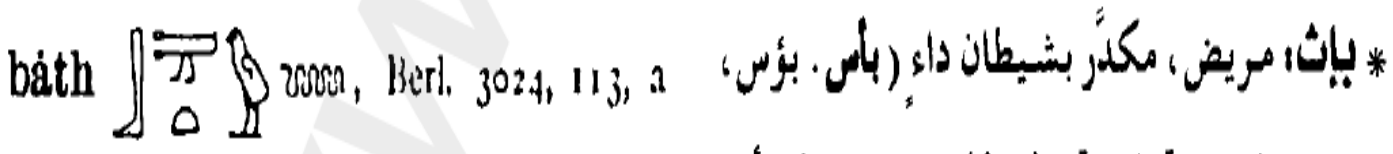

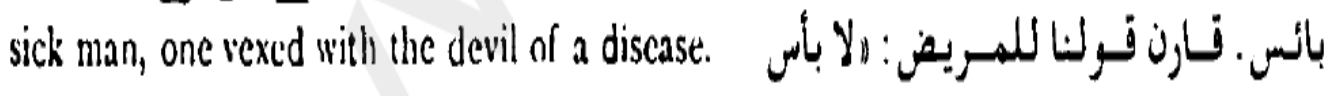
عليك" ) . (164) p.164

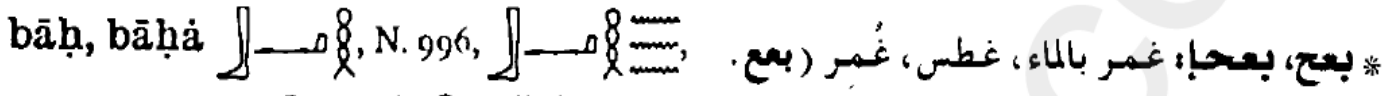

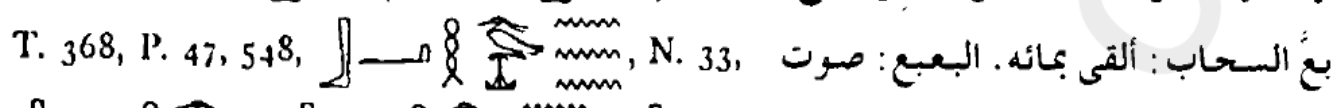

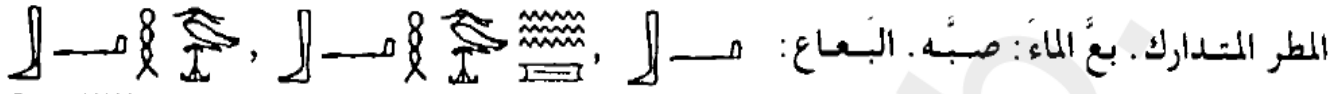
8

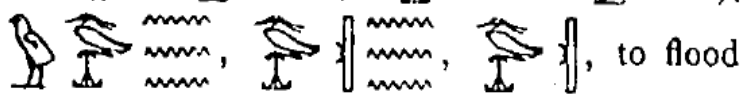
with water, to submerge, to be flooded 


\section{p.165}

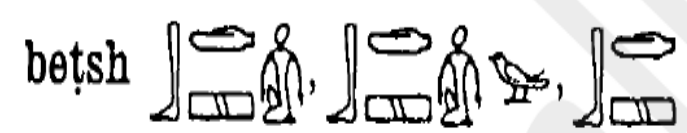

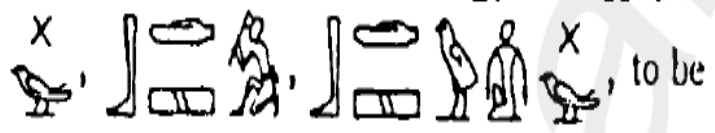
weak, helpless, exhausted, powerless, inpotent.

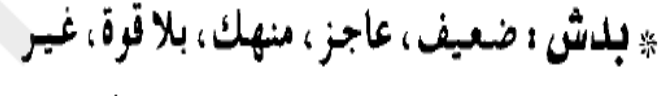

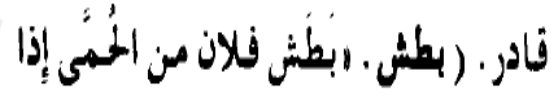
أفاق منها وهر ضميفم (اللسان) .

$$
\text { p.182 }
$$

per ${ }^{\square}, \square$, house, palace, seat of government

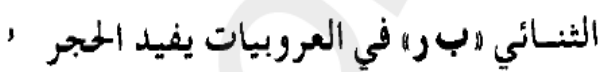

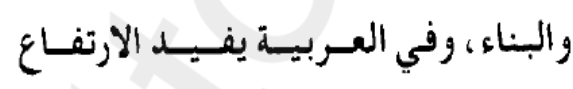$$
\text { والظهور - شأن البيت والقصر وركرسي }
$$

$$
\text { (') (الحكم ) }
$$

p.188

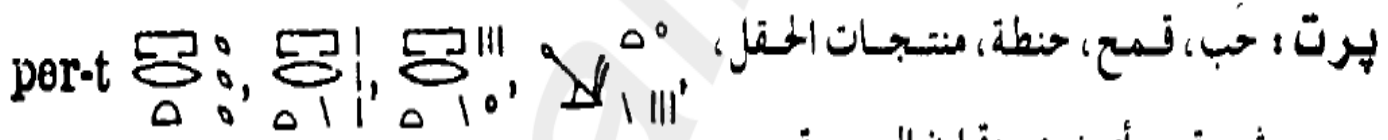

Peasant 294, grain, corn, wheat,

field produce, fruit of any kind; Copt. cpe,

ثمرة من أي نوع · (قارن العـ بيسة: برو. Bрнте, eßphre, Heb, ?ִ?

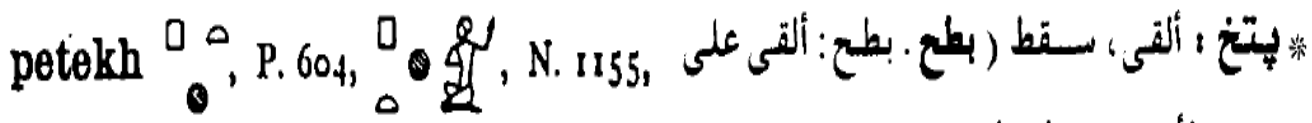

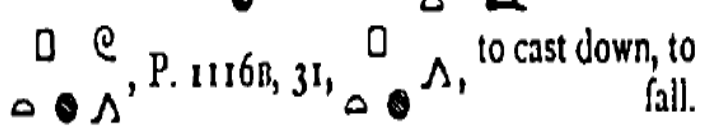
الأرض، بسط، طرح). p.206 


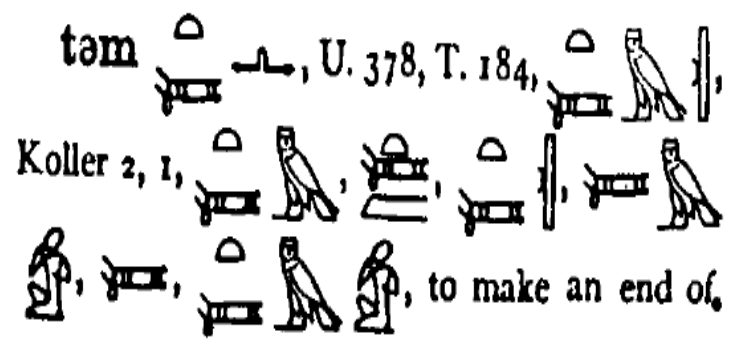

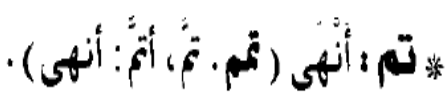

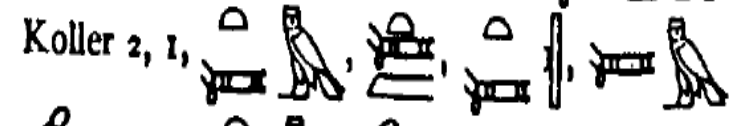

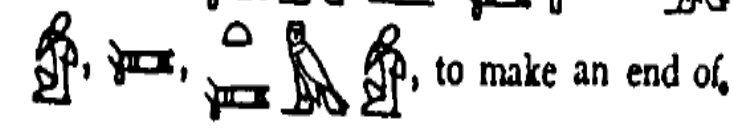

p.227

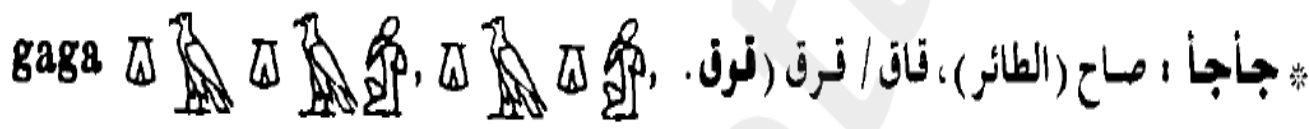
$10 \mathrm{cry}$ (of a bird), 10 cackle; var. $\frac{D}{6}$ g.

قاق الطائر : صام) .

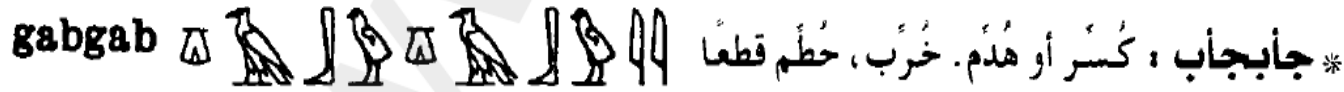

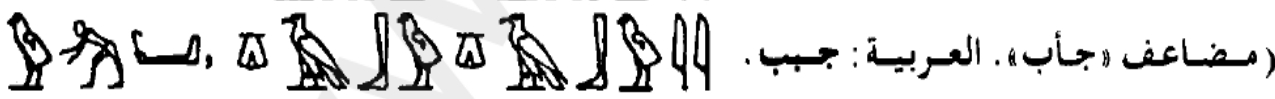

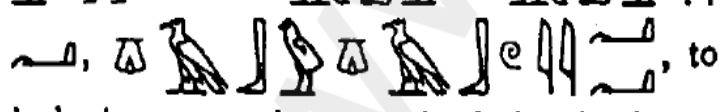

be broken or overthrown, to be dashed in pieces;

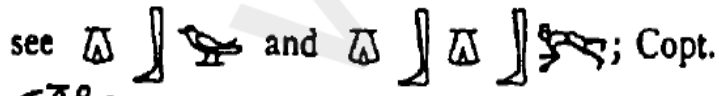
$\sigma \bar{B} B \in$.

p.242

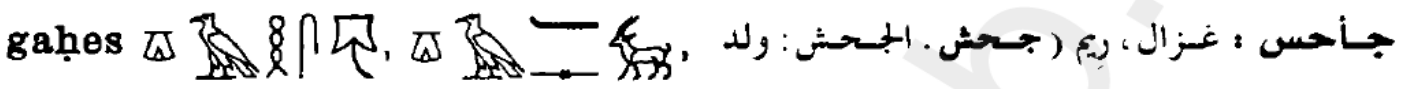
gazelle, antelope; fem. tब 8 व

plur. दs 8 \&

$8 \cap \uparrow ;$; Copt $\sigma_{\text {\&oc. }}$

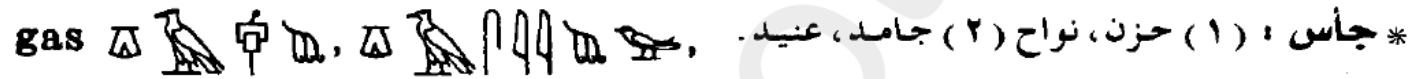
Love Songs 7, 6, grief, mourning, stiff, stiff (r) (1) necked; var. 
p. 244

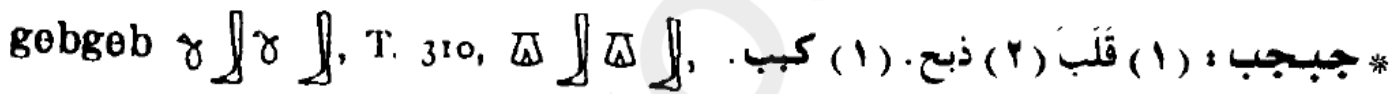

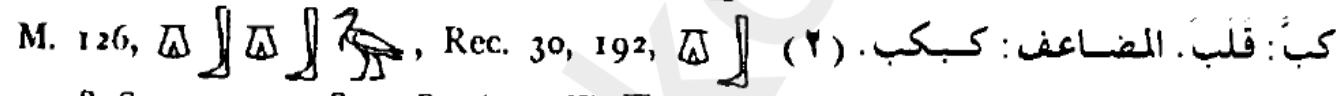
جله

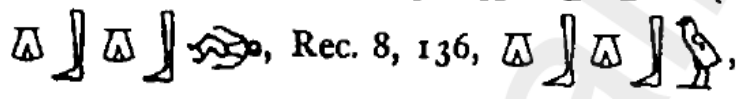
Stat. Tab. 39, to overthrow, to slay; is] $\left.\int \Delta\right]$ If 50 , the overthrown, slain; Copt.

hem-t $y, y, y, y, y$, $Y_{\triangle} \Delta \triangle D$, woman, wife; Copt. \&reet in

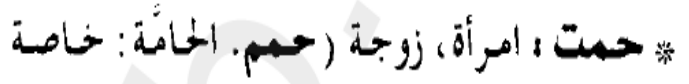

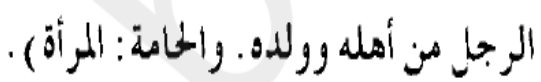
celeet

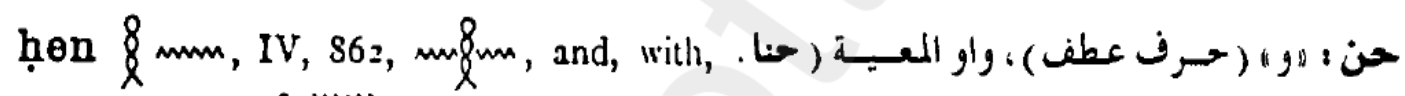
together with; see 8

لاحطظ أن هذه تســمى في العــربيسـة وار العطف ا أي تعطف ما لمق على ما سبق .

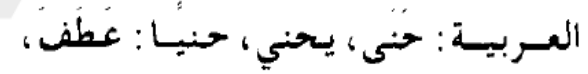
عطفًا) .

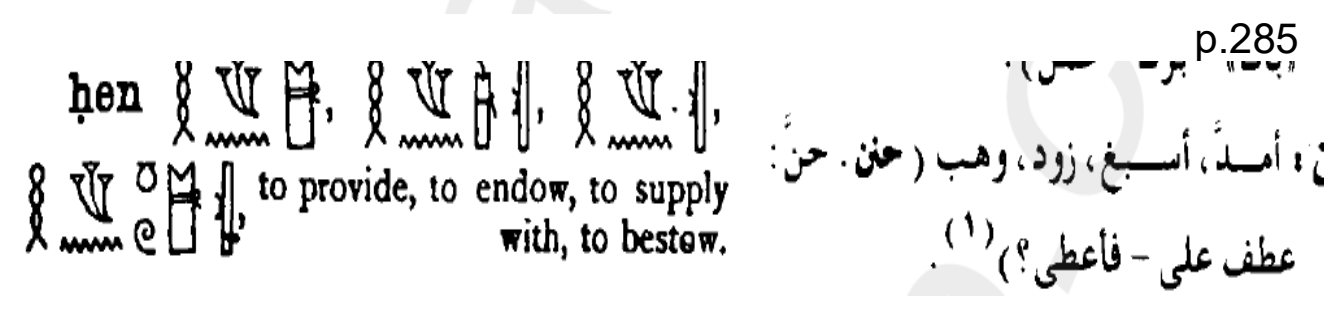

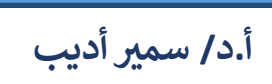
(كلمات مصرية قديمة في لغتنا العربية.) 


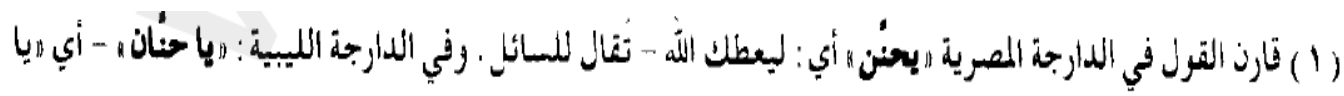

$$
\text { رزافق - ليرزقك - عند رد السائل. }
$$

p.287

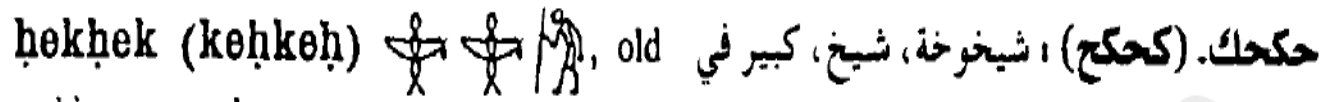
age, old man, aged.

$\therefore ., \pi \in R Q, \pi, 0 \quad \pi$

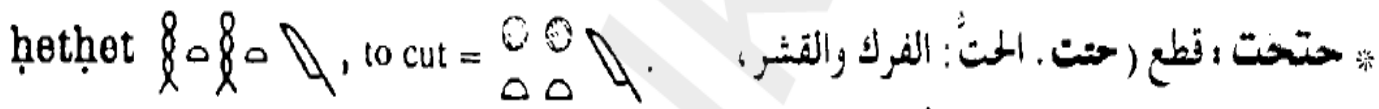

$$
\text { وقطع الورق من الغصن) (") }
$$

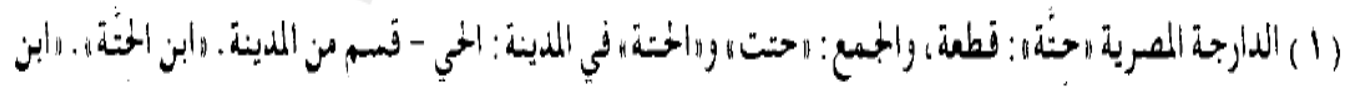

$$
\text { p.312 }
$$

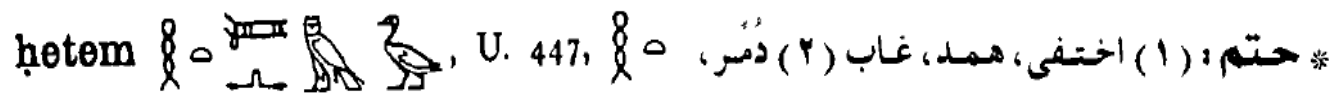
$\Omega$, T. 256 ,

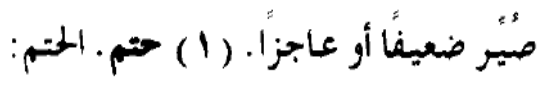

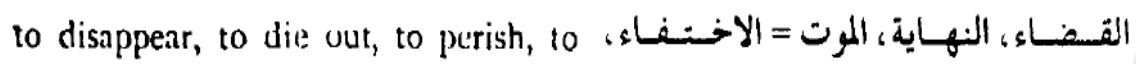

be destroyed, to render weak or helpless.

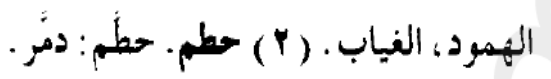

فلان حطمته السن: : إذا أسن" وضعف ).

p.316 


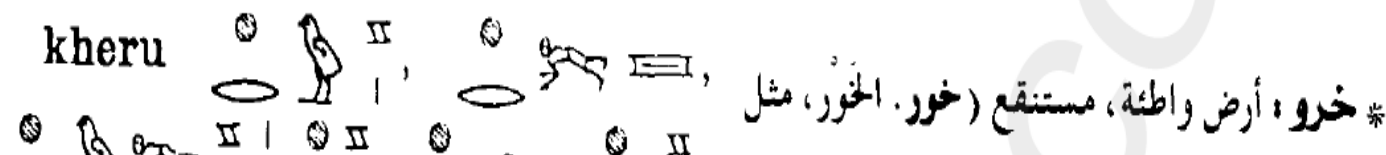

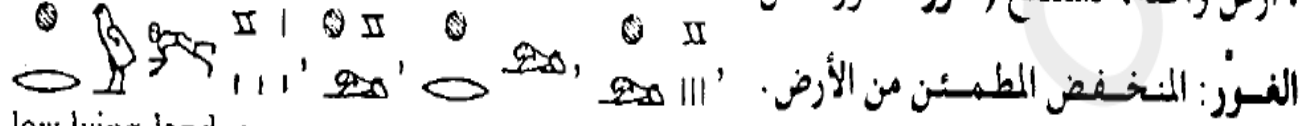
low.lying land, swamp.

وكذلك: الهور. الأهوار: المستنقعات)

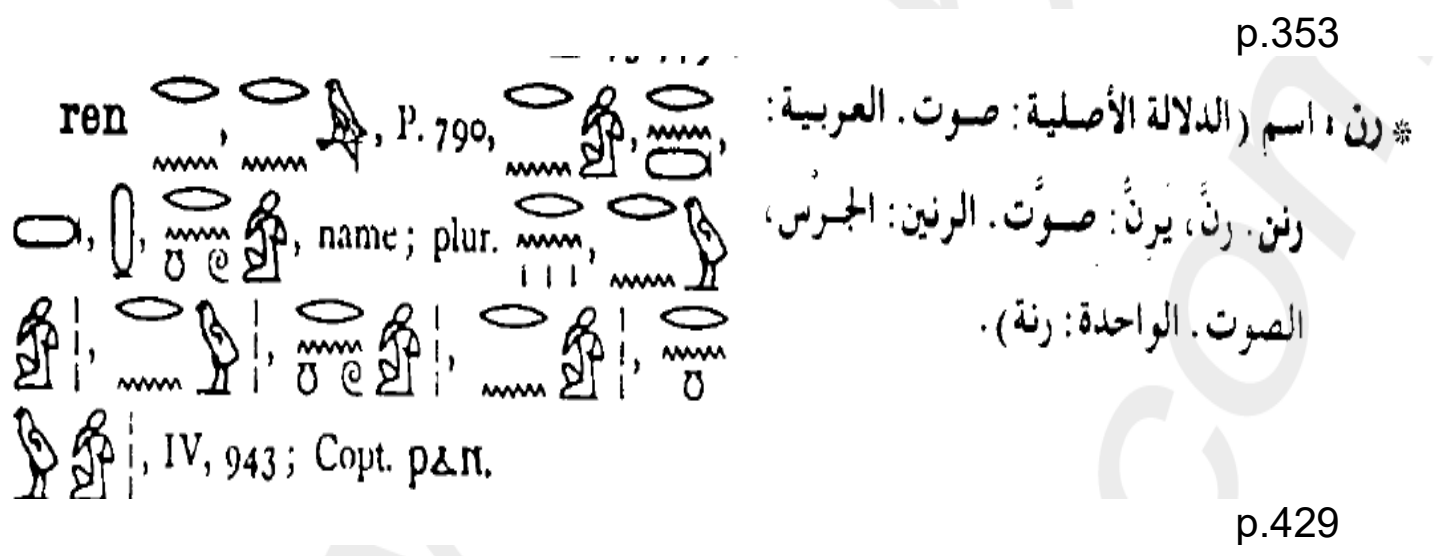

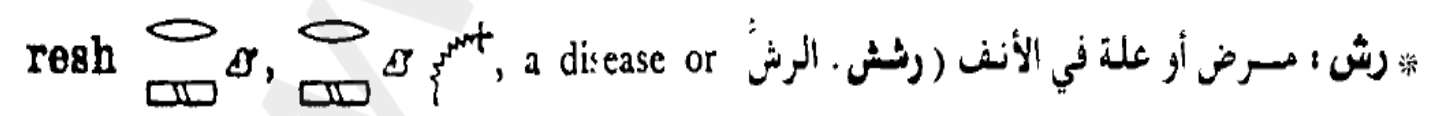
ailment of the nose.

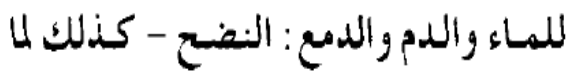

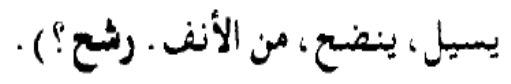
p.436 


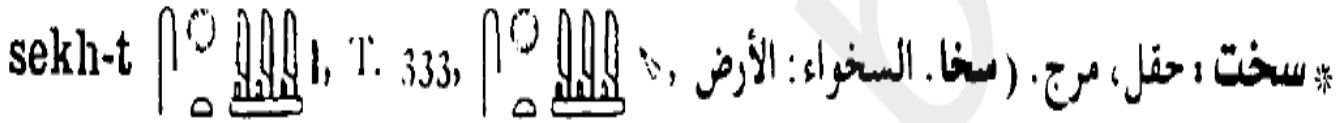

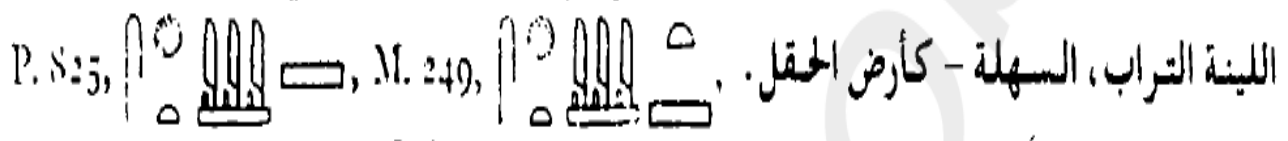

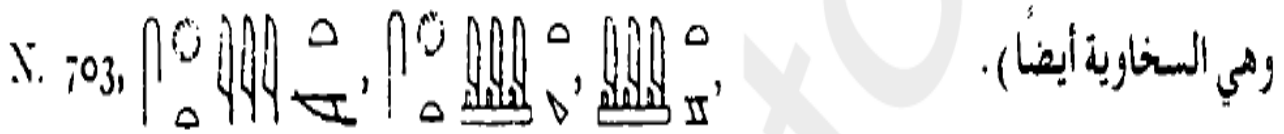

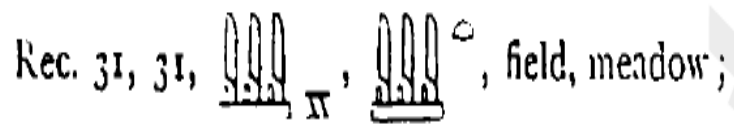

skher | $3 \circ \mathrm{B}$ (Ani), to ofiend (?)

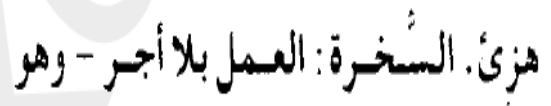

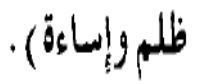
p. 490 $\operatorname{sen} \overline{\min _{0}} \square$, Rev. 14, 34, clay.

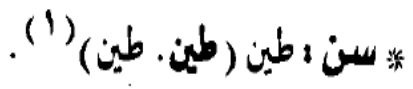

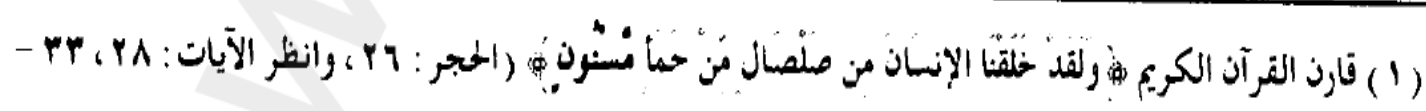

$$
\text { من منس السورة) . }
$$




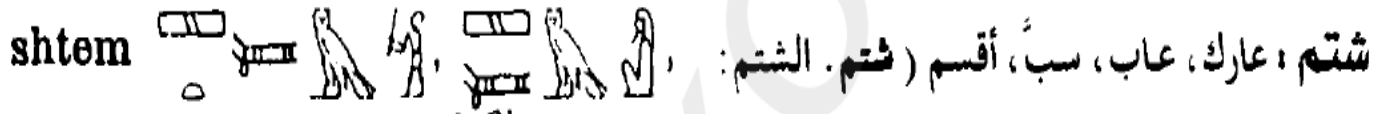

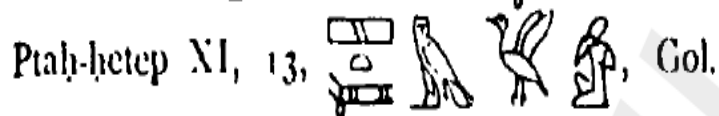

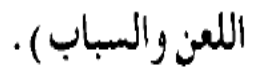
Ham. If 547 , to fight, to revile, to curse, to

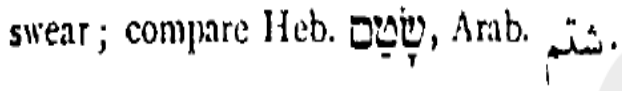

\section{āmā, āmām}

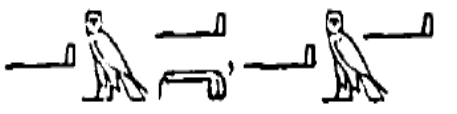

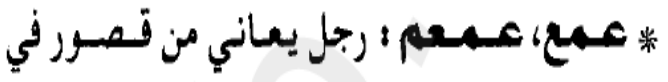
at a man suffering from some defect of the sexual orgams

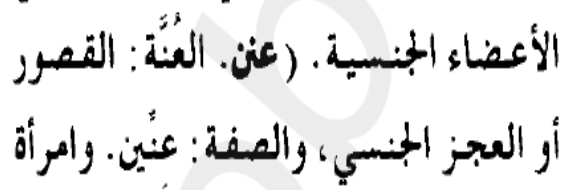
āmā Inet1. 24, 13, a disease Do 0 III' of the sexual organs.

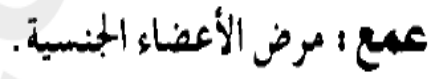

p.620

qembu $\triangle$ \& 8 , T. 57, M. 217 ,

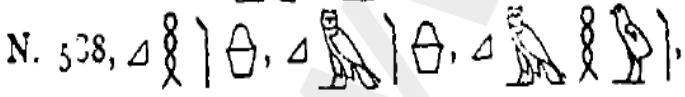
* قسحو ؛ خبز مصنوع من دقيق فاخر ( لمح.

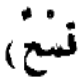

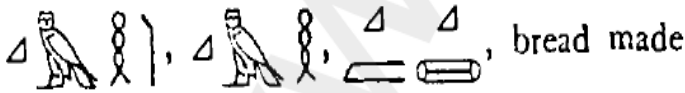
of fine flour; compare Heb. تص

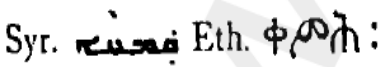

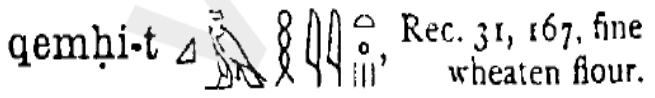
تنهيت ، دتيّ حنطة فاخر . p.668

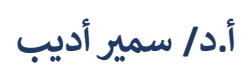
(كلمات مصرية قديمة في لغتنا العربية.) 


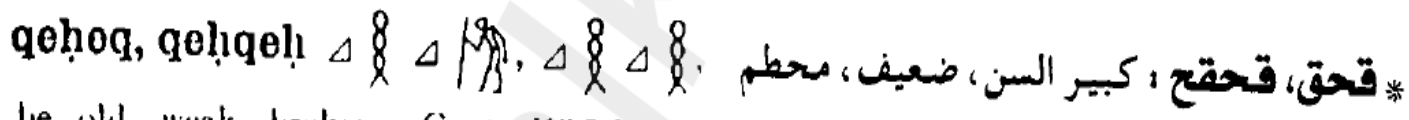

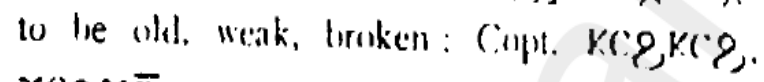
$x \in \gtrless \times \bar{\varepsilon}$.

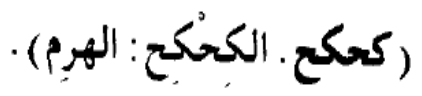

p.673

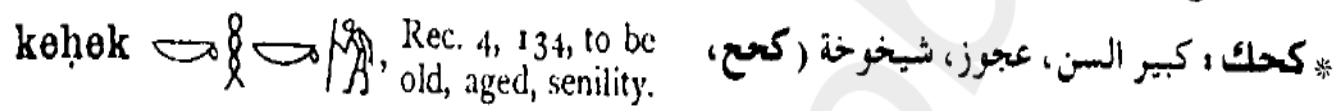

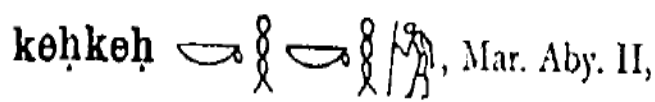

كحكع . الكحكح : العجوز ) . 36, Rac. 16, 57, Anastasi I, 2, 1, to be old.

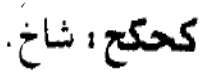

p.691

mit 440, T. 290, N. 167, O, N. 329 , Hh. 344 , to die.

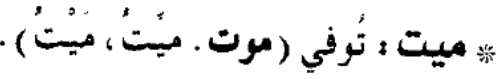

mitiu $=44_{\text {III }}^{\circ}$ 空 $1,=44$ S

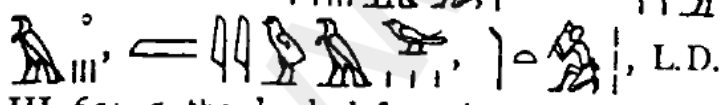

ميتيو : المثوفَى ، هزيمة ، مجزرة.

III, 65A, 5, the dead, defent, slaughter.

p.717

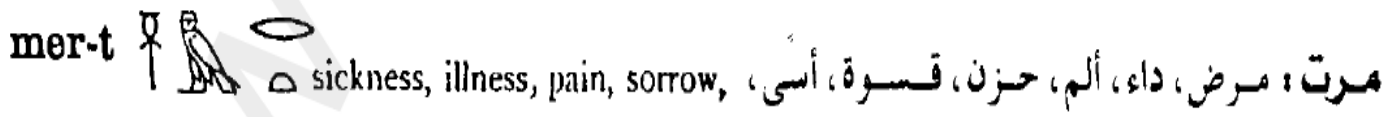
cruelty, grief, fatal disease

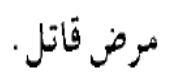

741

أ.د/ سمير أديب

(كلمات مصرية قديمة في لغتنا العربية.) 


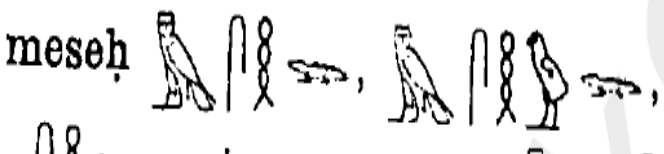

Af 180, Amen, $4,16,22,9,18$

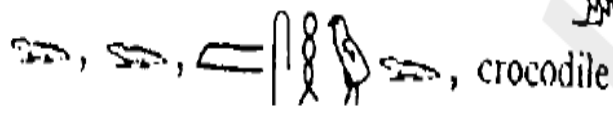

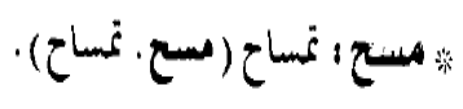

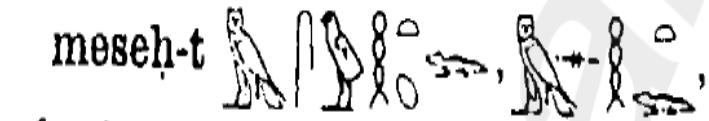

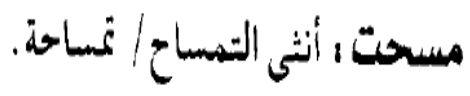

a fimale crocodile.

p.753

na man wind, air, breeze

$$
\begin{aligned}
& \text { 㫧 } \\
& \text { ريح النّتاء العاصفة) . } \\
& \text { p.769 }
\end{aligned}
$$

nu 8 की 88 , child, son, (val)e; plur.

5 if , children.

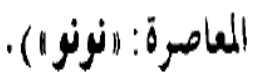

har 网 0

E, pond, lake, sheet of water; var.

p.776

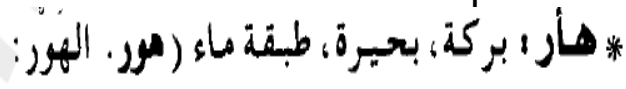

بحيرة فيها مياه غياض وآجام، فتتسع

ويكثر ماؤها، والجمع: أهرار) .

p.848

أ.د/ سمير أديب

(كلمات مصرية قديمة في لغتنا العربية.) 


\section{ium (daum ?) AH P}

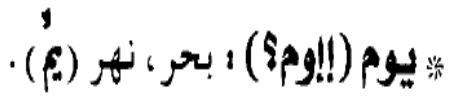

sea, river; Hcb. ים, Copt. Eloe, Ise, soe

p.907

\section{الخاتمــة}

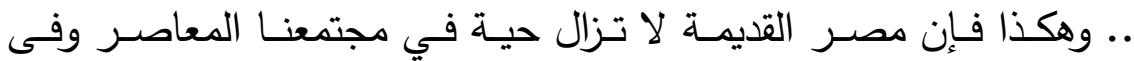

أوساطه الشعبية والريغية على وجه الخصوص، بروحها وعاداتها وتقاليدها، التي تتم عن الأصالة واحترام التراث.

وبعـد فإنـه يتضـح لنـا مـن هذا البحـث أنـه في لغتــا العربيـة الكثيـر مـن

المسميات والمفردات الفصحى والعامية التي لا زلنا نستخدمها حتى الآن والتي ترجع بأصولها للغة المصرية القديمة. 


\section{هوامش الدراسة}

أ- أحمد بدوى و هرمان كبس ، المعجم الصغير في مفردات اللغة المصرية القيمة ، القاهرة ،

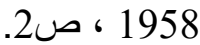

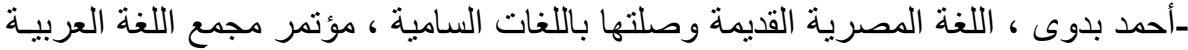

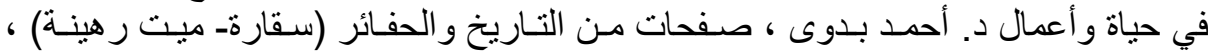

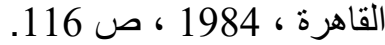

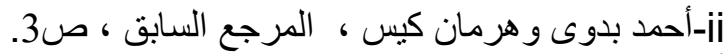

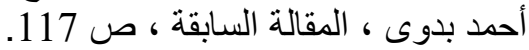
.Wb. I, p. 33-iii

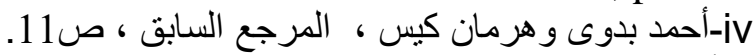

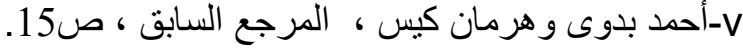

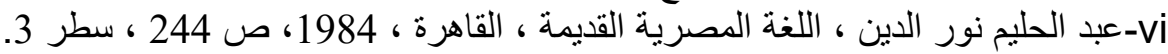

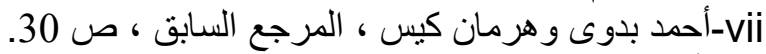

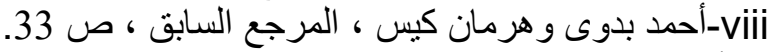

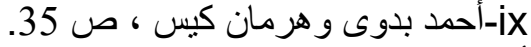

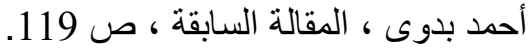

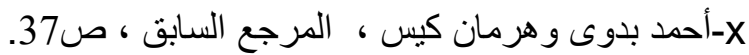

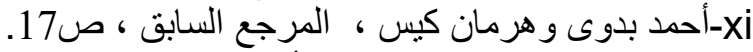

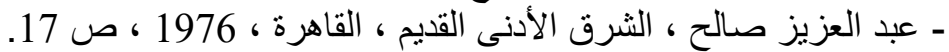

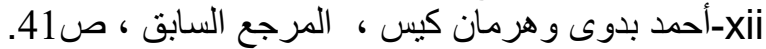

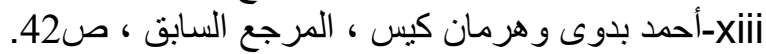

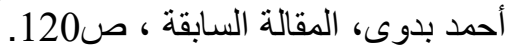

J. Cerny, Coptic Etymological Dictionary, Cambridge. 1976, p. 10-xiv

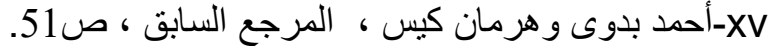

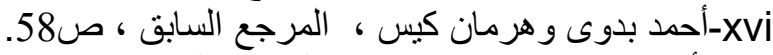

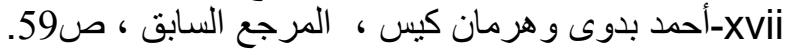

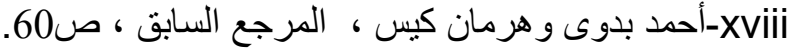

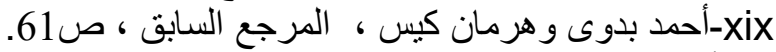

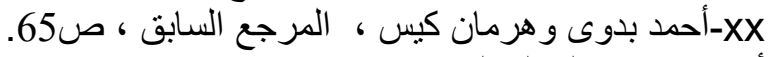

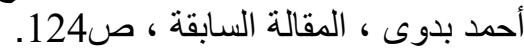

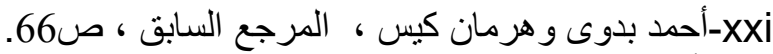

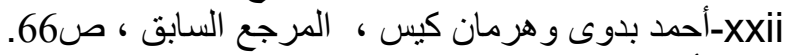

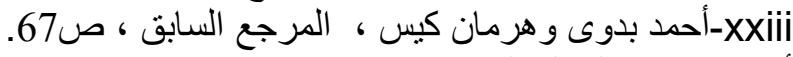

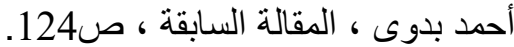

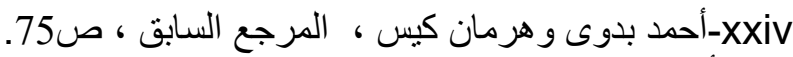

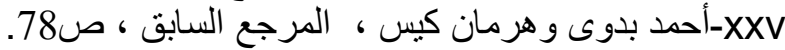

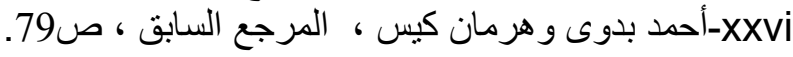


أحمد بدوى ، الدقالة السابقة ، ص121.

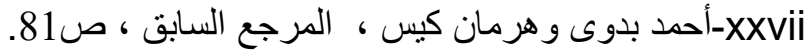

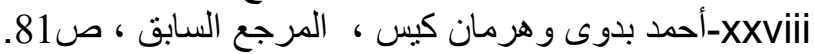

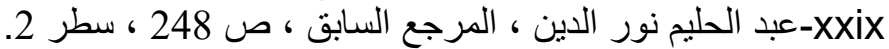

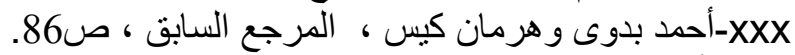

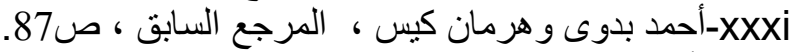

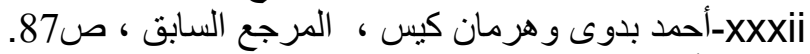

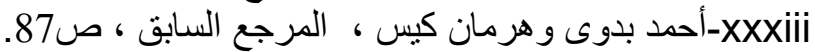

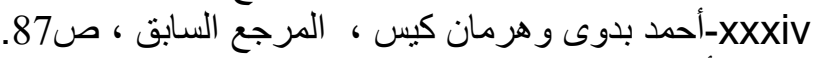

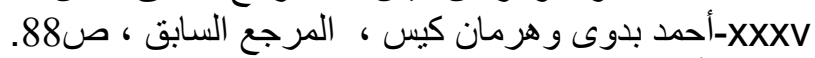

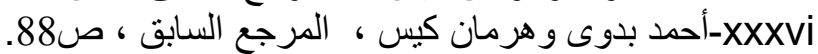

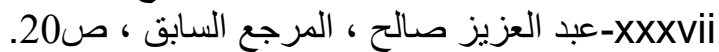

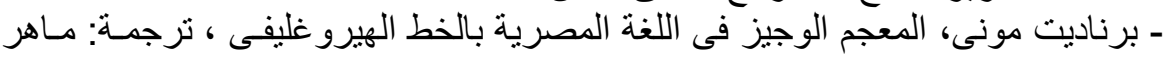

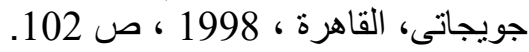

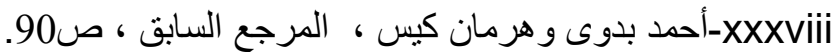

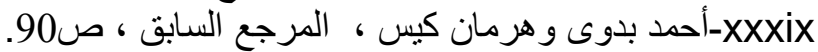

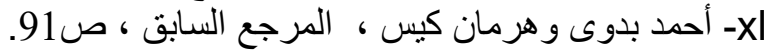

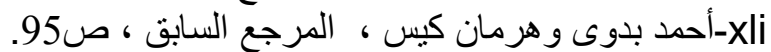

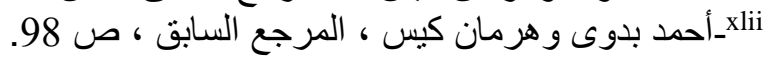

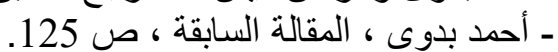

- أحمد بدوى و هرمان كيس ، المرجع السئة السابق ، ص103.xliii

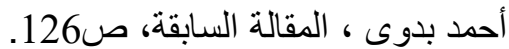

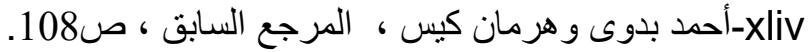

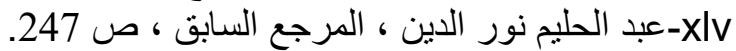

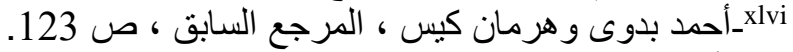

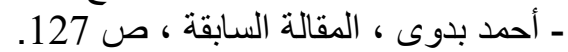
- أحمد بدوى وهرمان كيس ، المرجع السابق ، ص122-xIvii J. Cerny, Op.cit., p. 288- ${ }^{\text {xlviii }}$ J. Cerny, Op.cit., p. 76- $-^{\text {xlix }}$

أ-أحمد بدوى وهرمان كيس ، المرجع السابق ، ص124.

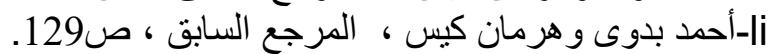

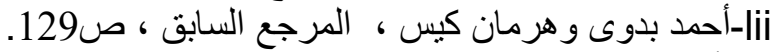

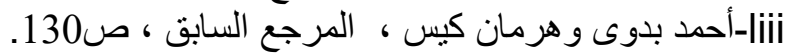

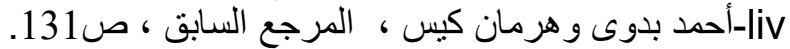

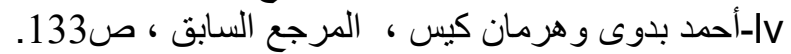

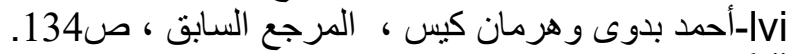
J. Cerny, Op.cit., p. 75-lvii

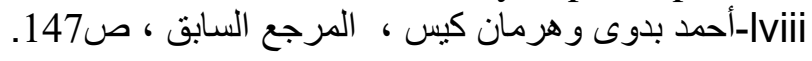




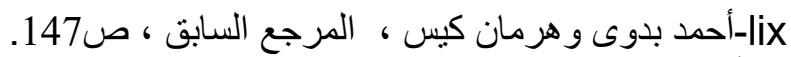

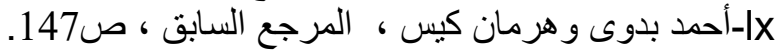

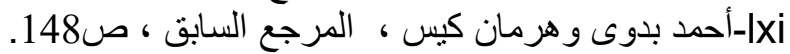

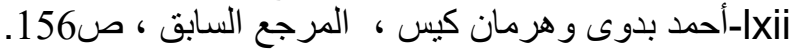
.Wb. III, p. 64- - $^{\text {lxiii }}$

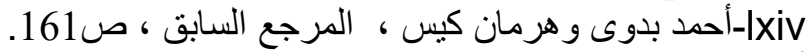

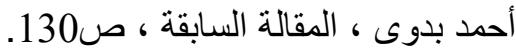

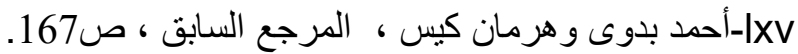

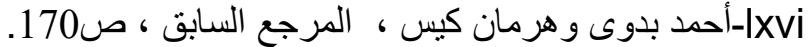

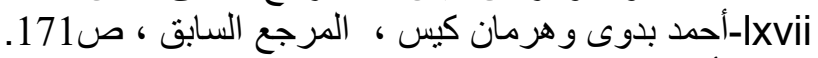

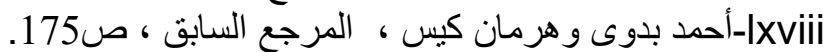

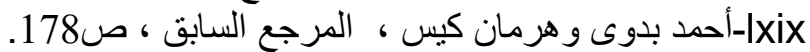

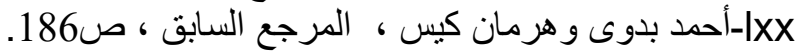

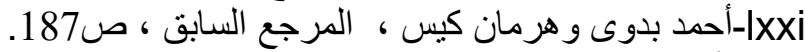
Ixxii

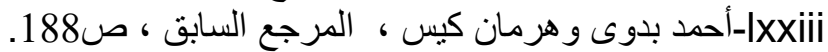

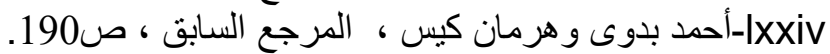

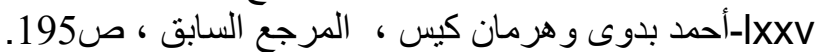

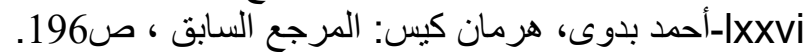
انظر عبد العزيز صالح ، المرجـع السـابق ، ص20 العيد ، وأحمد بـدوى ، المقالـة السـابقة ، ص .199

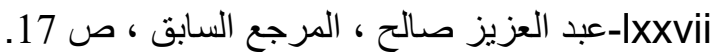

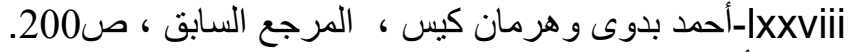

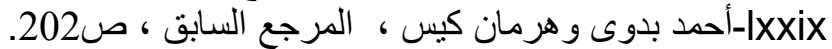

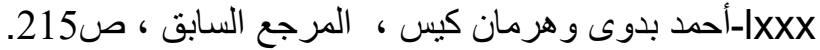

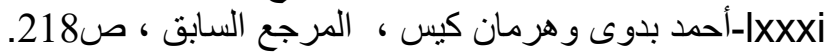
J. Cerny, Op.cit., p. 151-Ixxxii Iأحمد بدوى وهرمان كيس ، المرجع السابق ، ص227xxiii

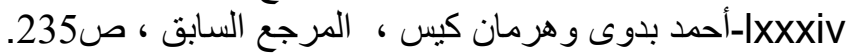

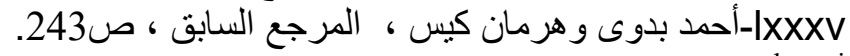
.Wb. IV, p. 422-1xxxvi J. Cerny, Op.cit., P. 263-1xxxvii

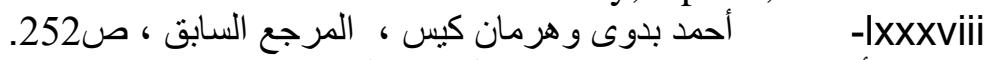

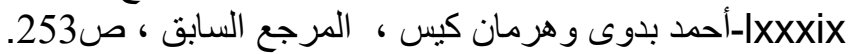

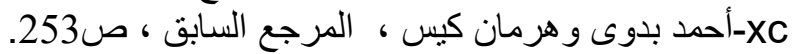

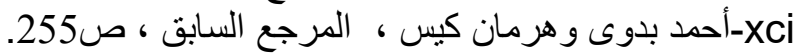

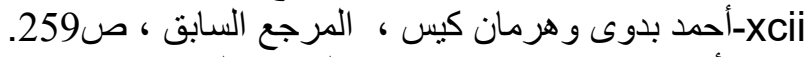

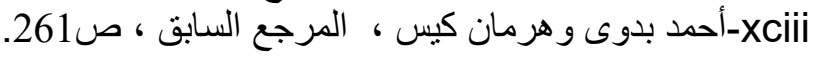


J. Cerny, Op.cit., P. 63- ${ }^{\text {xciv }}$

- عبد الحليم نور الدين ، المرجع السابق ، ص248-XCV

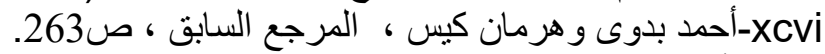

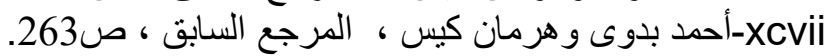

J. Cerny, Op.cit., P. 341-xcviii

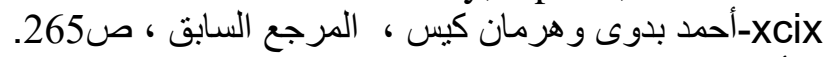

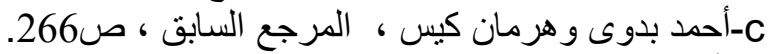

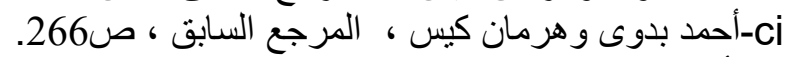

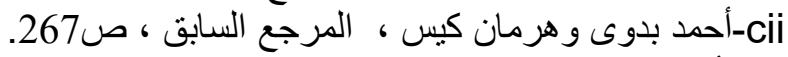

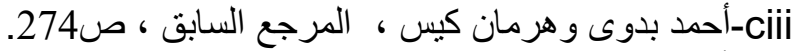

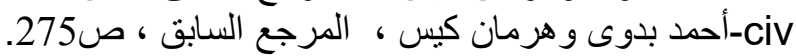

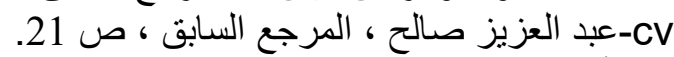

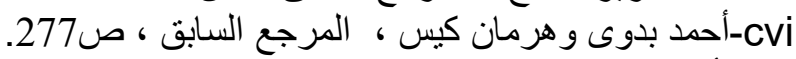

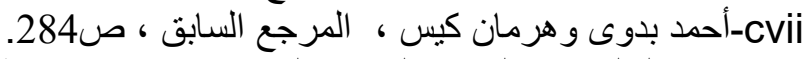
ceviii

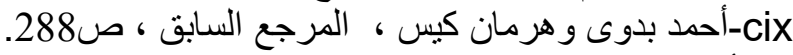

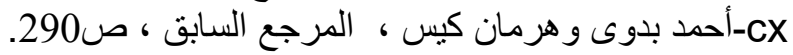

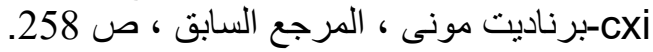

Cxii

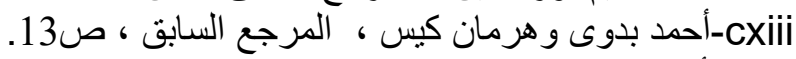

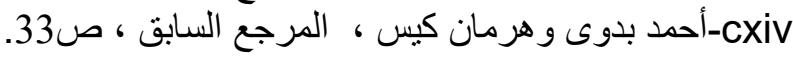
.Wb. I, p. 237-cxv

cxvi

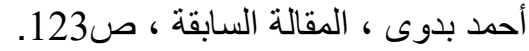

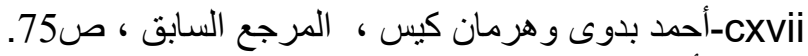
-cxviii -cxix

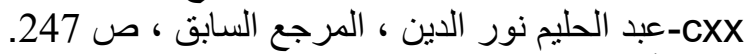

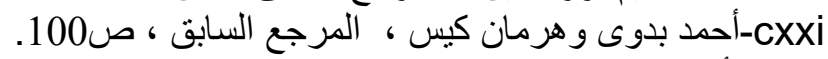

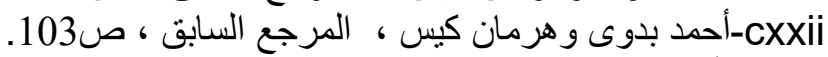

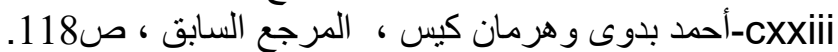

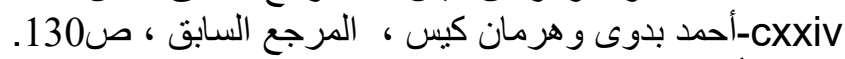

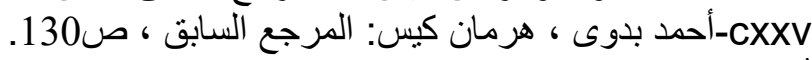
J. Cerny, Op.cit., P. 75-cxxvi -Cxxvii

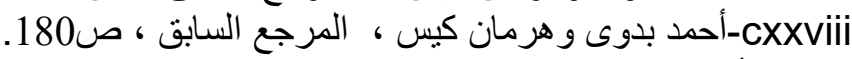

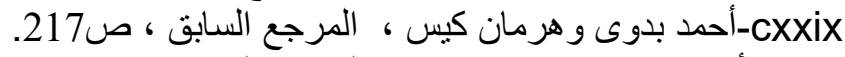

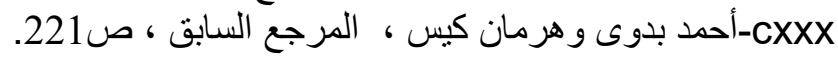




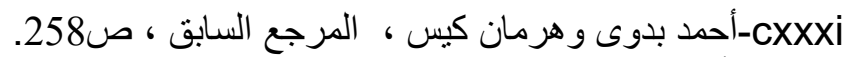

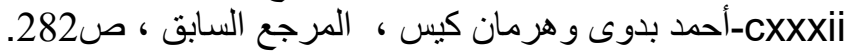

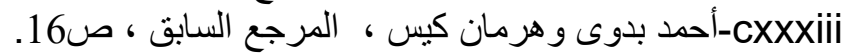
CXXXiv

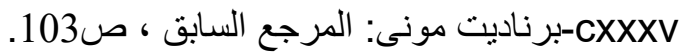

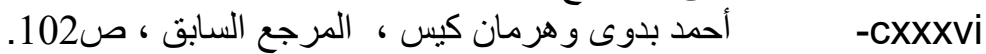

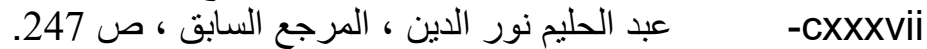

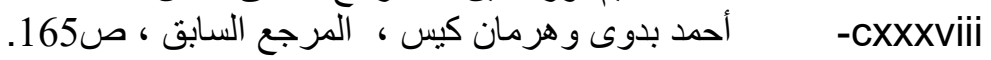

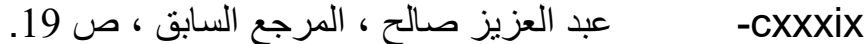
-

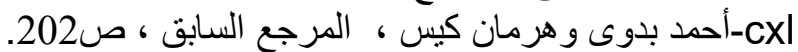

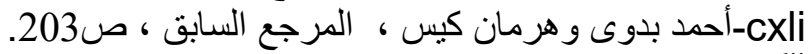
J. Cerny, Op.cit., P. 252_cxlii

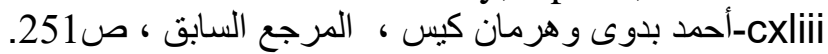

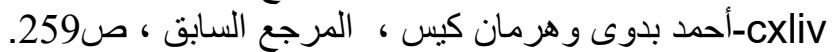

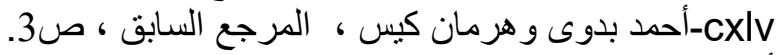

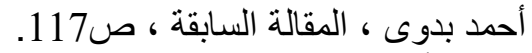

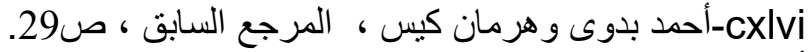

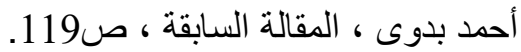

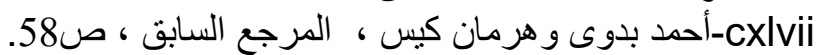

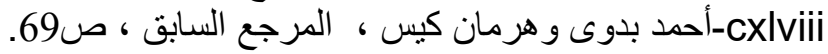
-cxlix

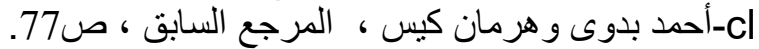

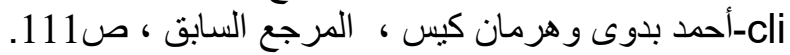
.Wb. III, p. 453-clii

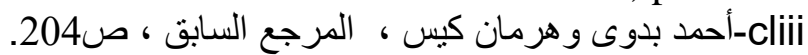

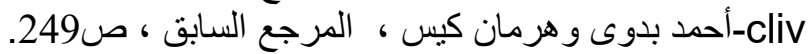

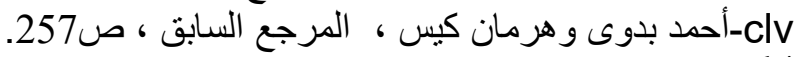
J. Cerny, Op.cit., P. 339-clvi

G. Sobhy, "Miscellanea", in JEA, 16, London, 1930, p. 5-clvii J. Cerny, Op.cit., P. 185-clviii

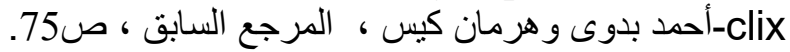

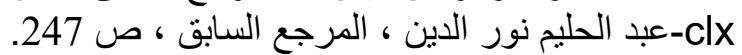

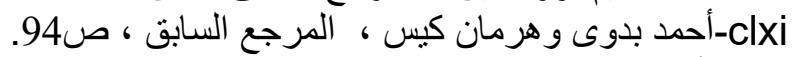

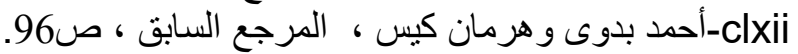

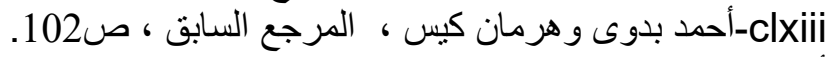
أحمد بدوى ، الدقالة السابقة ، صدان كئ126. أحمد بدوى و هرمان كيس ، المرجع السابق ، ص108. clxiv 
.Wb. III, p. 93-clxv

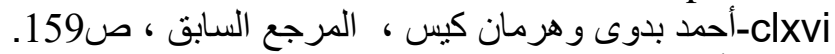
أحمد بدوى وهرمان كيس ، المرجع السابق ، ص2lxvii

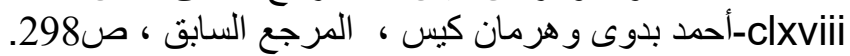
J. Cerny, Op.cit., P. 74-clxix J. Cerny, Op.cit., P. 56- ${ }^{\mathrm{clxx}}$ .Wb. V, p. 72-clxxi J. Cerny, Op.cit., P. 97-clxxii J. Cerny, Op.cit., P. 327-clxxiii .Wb. V, p. 262_clxxiv

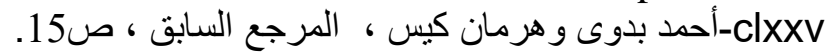

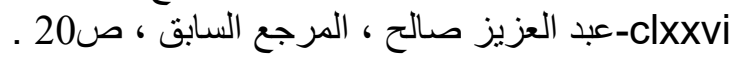
-

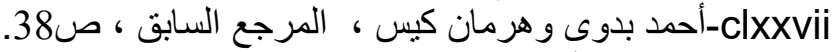

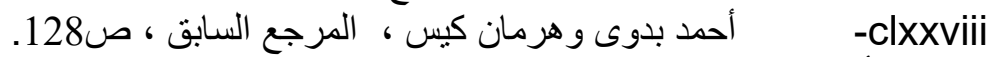

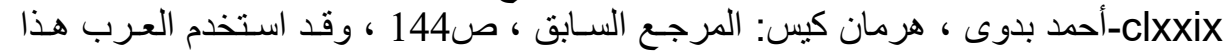

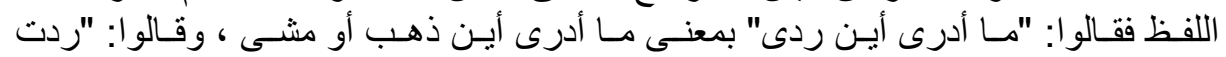

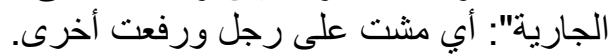

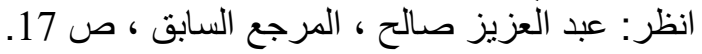

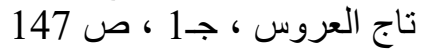

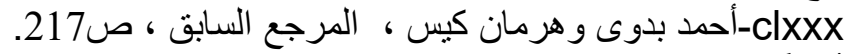
.Wb. IV, p. 99_clxxxi

أحمد بدوى وهرمان كيس ، المرجع السابق ، ص261xxxii

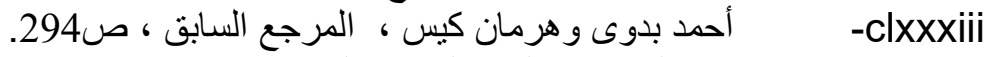

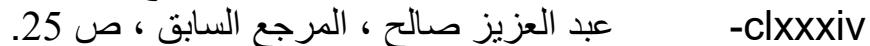

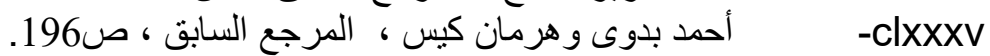

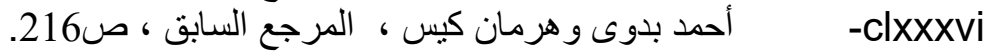

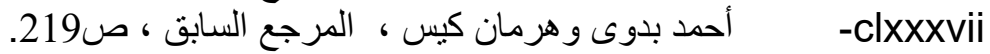

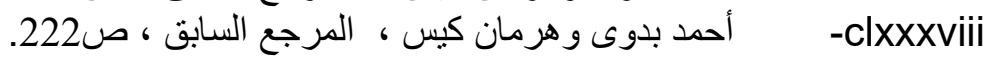
Clxxix

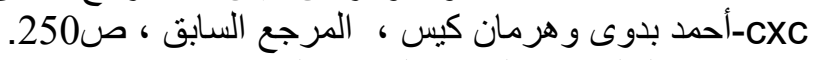

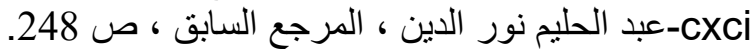
cxcii

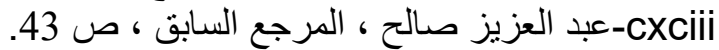
وليم نظير ، العادات المصرية بين الأمس و اليوم ، القاهرة ، 1967 ، 1967 ، ص 83. صان -Cxciv ص138. n n 


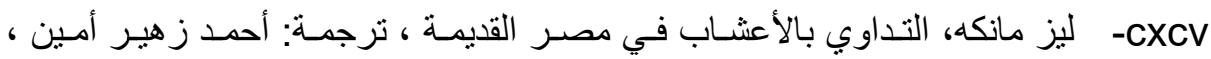

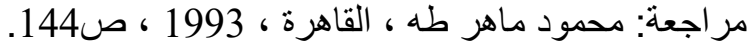

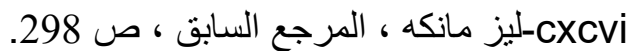
 

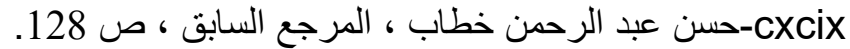

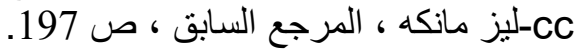

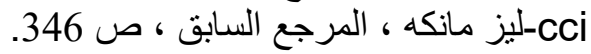

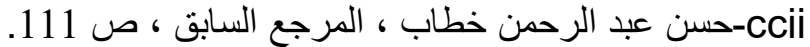
-cciii

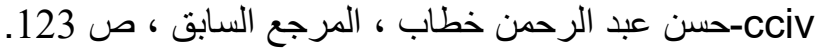

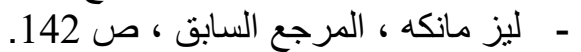

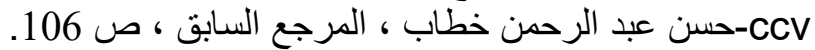

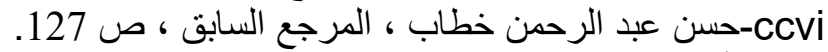

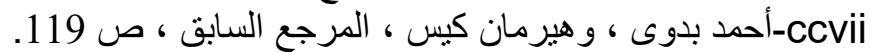

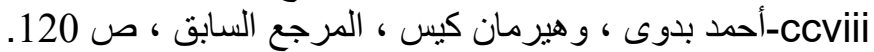

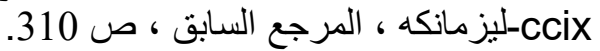

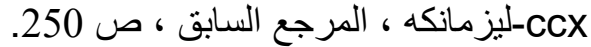

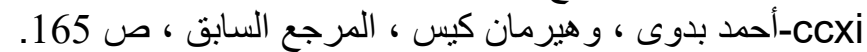

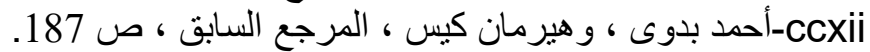

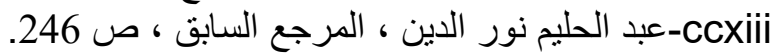

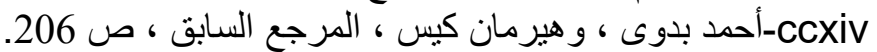

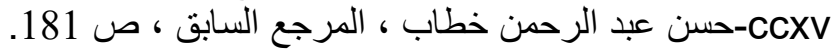

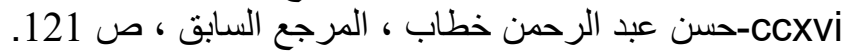

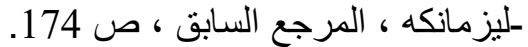

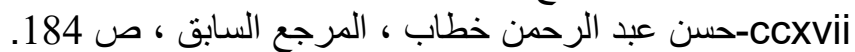

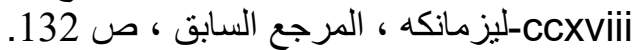

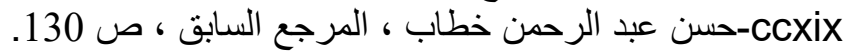

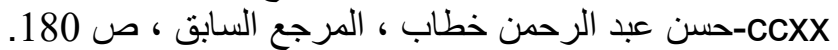

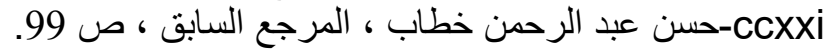
Coxxii -CCXXiii

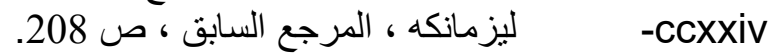

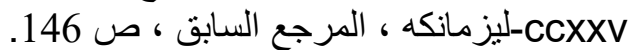

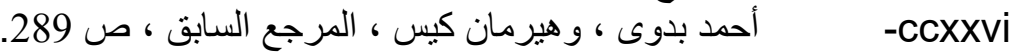

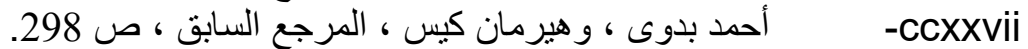

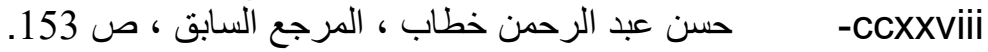
- ليزمانكه ، المرجع السابق ، ص الرحن 283. 
J. Cerny, Op.cit., P. 46-cxxix

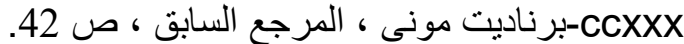

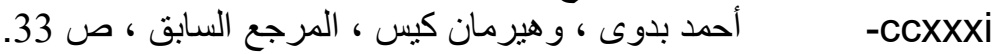

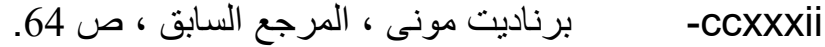

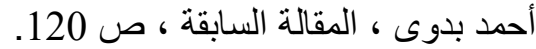

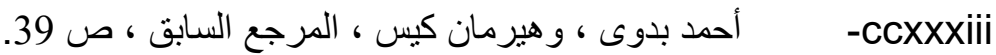

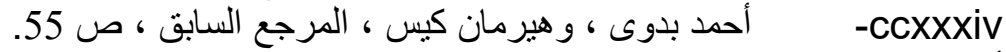

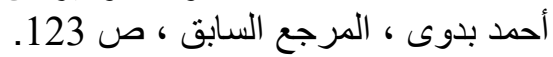

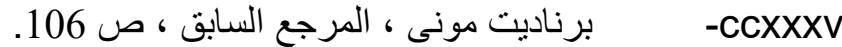

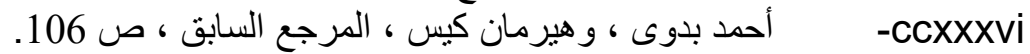

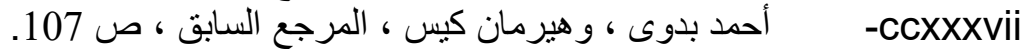

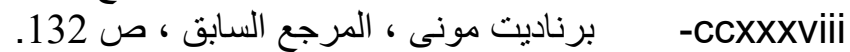

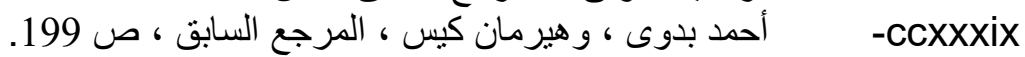

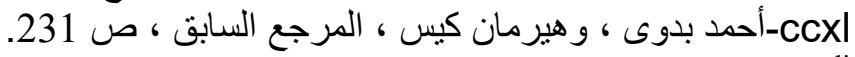
.Wb. V, p. 59_ccxli

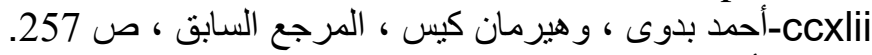
CCCXliii

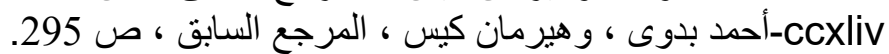

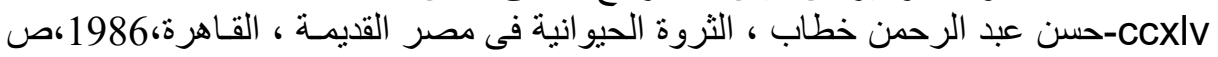
.193

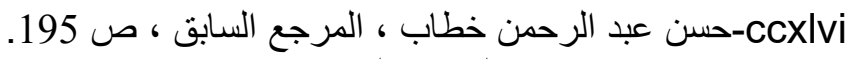

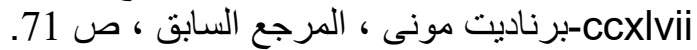

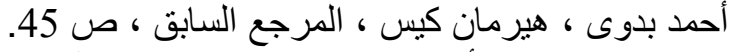

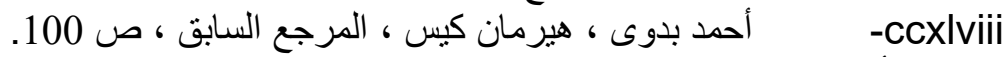

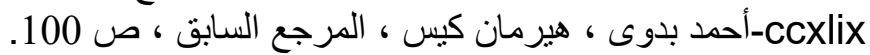

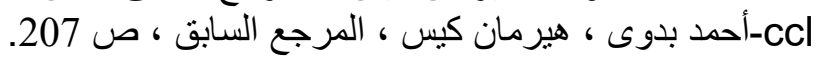

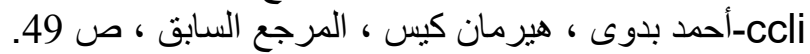

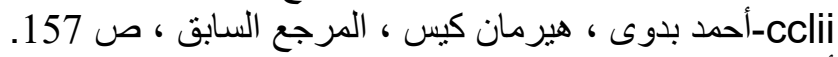

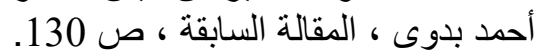

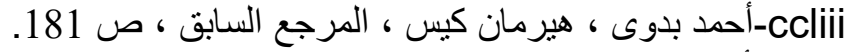
(3)-ccliv

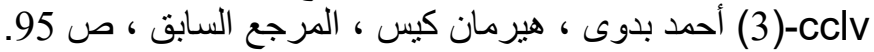

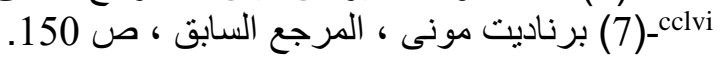
cclvii

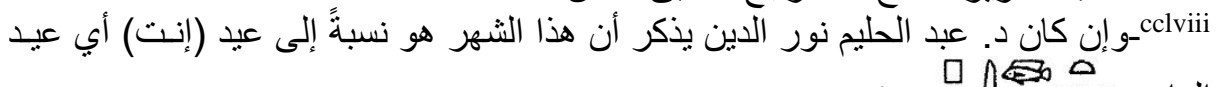

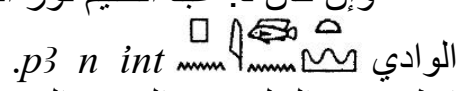

انظر: عبد الحليم نور الدين ، المرجع السابق ، ص 249 (2). 
مجلة جامعة مصر للدراسات الإنسانية (العلوم الاجتماعية والإنسانية) مجلد 1 عدد 1 يناير (2021)

cclix

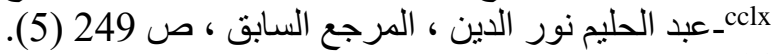

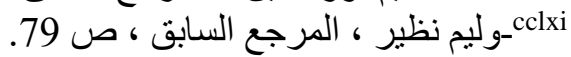

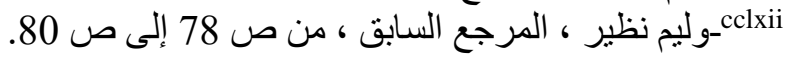




\section{مراجِع عامة}

أولاً: مراجع عربية:

1 - حجازي ،محمد فهيم ، علم اللغة العربية ، الكويت، 1973.

2 - سمير أديب ، موسوعة الحضـارة المصرية القديمـة ،"الهوروث من تراثـا

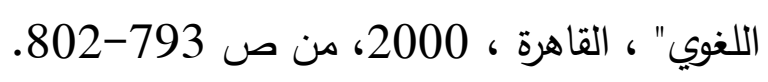

3 - عبد الحليم نور الدين : قواعد اللغة الصصرية القديمة ، القاهرة، 1998. 4 - على فهمي خشيم ، آلهة مصر العربية ، المجلد الثاني ، القاهرة ، 1998

5 - علي فهمي خثيم ، البرهان على عروبة اللغة المصرية القديمة ، القاهزة ، .2007

\section{ثانياً: مراجع أجنيية:}

1-Gardiner, A., Egyptian Grammar, Oxford, 1978.

2-Faulkner, O.R., A Concise Dictionary of Middle Egyptian, Oxford, 1976.

3-Cerny, J., Coptic Etymological Dictionary, Cambridge, 1976.

4-Erman, A. Und Grapow, P., Worterbuch der Agyptischen Sprache, Leipzig, 1926-1953 (5 Bande + Belegestelle).

5- Collier, Mark and Bill Manley. How to Read Egyptian Hieroglyphs. Univ. of California Press, 1998. 
مجلة جامعة مصر للدراسات الإنسانية (العلوم الاجتماعية والإنسانية) مجلد 1 عدد 1 يناير (2021)

6- $\quad$ Forman, Werner and Stephen Quirke Hieroglyphs and the Afterlife in Ancient Egypt. University of California, 1996.

7- Foster, John. Hymns, Prayers and Songs: An Anthology of Ancient Egyptian Lyric Poetry. Scholars Press, 1995.

8- Hoch, James. Middle Egyptian Grammar. SSEA (Toronto), 1995. (spiral bound)

9- Murnane, William. Texts from the Amarna Period in Egypt. Scholars Press, 1995.

10- Parkinson, Robert, Voices from Ancient Egypt: An Anthology of Middle Kingdom Writings. University of Oklahoma Press, 1991.

11- Parkinson, Robert and Stephen Quirke, Papyrus. University of Texas Press, 1995.

12- Wente, Edward, Letters from Ancient Egypt. Scholar's Press, 1990.

13- Wilkinson, Richard, Reading Egyptian Art. Thames and Hudson, 1992.

14- Zauzich, K-T., Hieroglyphs without Mystery. Univ. of Texas, 1992

15- Allen, James P. (2000) Middle Egyptian: An Introduction to the Language and Culture of Hieroglyphs.

16- Depuydt, Leo (2000) Fundamentals of Egyptian Grammar, Part 1: Elements.

17- Hoch, James (1996) Introduction to Middle Egyptian Grammar.

18- Junge, Friderich (2001) Late Egyptian Grammar. 
19- Lesko, Leonard (2002) Dictionary of Late Egyptian, 2 Vols.

20- Loprieno, Antonio (1995) Ancient Egyptian: A Linguistic Introduction.

21- Malek, Jaromir (1994) ABC of Egyptian Hieroglyphs.

22- Ockinga, Boyo G. (1998) A Concise Grammar of Middle Egyptian.

23- Wilkinson, Richard H. (1992) Reading Egyptian Art: A Hieroglyphic Guide to Ancient Egyptian Painting and Sculpture.

24- Zauzich, Karl-Theodor (1994) Hieroglyphs Without Mystery. 


\section{Ancient Egyptian words in our Arabic language Prof.Dr. Samir Adeeb}

\section{$\underline{\text { Abstract }}$}

By studying the Arabic language and the ancient Egyptian language, it was found that they are of the same origin, and then they were separated by what they entered from the heart and substitution, as happened in all ancient languages. Arabic vocabulary has an equal in

The ancient Egyptian language, the Coptic language which is the last stage of the development of the ancient Egyptian language - remained in circulation in the country until the seventh century $\mathrm{AD}$, then it was replaced by the Arabic language, and the use of the Coptic language became limited to rituals in churches.

The ancient Egyptian language has the rigid noun, the derivative, the verb with its times, and the adverb

(Adverbs of time and adverbs of place), conjunctions, remembrance and femininity, then singular, dual and plural, connected and separate pronouns, construction for the known and unknown, the adjective following the described, the direct addition, the addition with the lam (such as your saying is the book of Muhammad and the book of Muhammad), then the lineage with yaa, and in it the case and distinction The noun sentence and the actual sentence ... etc.

أ.د/ سمير أديب

(كلمات مصرية قديمة في لغتنا العربية.) 
Perhaps the most indicative of the ancient relationship between the ancient Egyptian language and the Arabic language is the existence of essential links between the grammar rules in each of them, despite the different forms of writing between them, including:

The presence of the letters $\mathrm{H}$, Al-Ain and Qaf in the ancient Egyptian language. The prevalence of the triple source for its verbs, the predominance of the other defective verb in it, preceding the subject verb, appending the adjective to the described, the use of the Muthanna form, adding the feminine $t$ at the end of some nouns and feminine adjectives, the use of the Y ratio, distinguishing some from all.

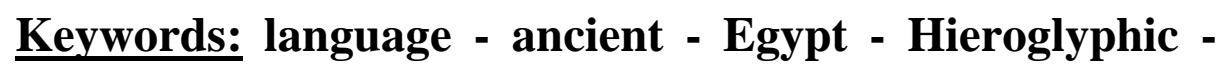
Arabic. 